\title{
Detailed Hydrogeological and Hydrochemical Reassessment of Coastal Basins of Southwestern Nigeria
}

\author{
Saadu Umar Wali*, Ibrahim Mustapha Dankani², Sheikh Danjuma Abubakar ${ }^{2}$, Murtala Abubakar Gada² and Kabiru Jega Uma ${ }^{3}$ \\ ${ }^{1}$ Department of Geography, Federal University Birnin kebbi, P.M.B 1157, Kebbi State, Nigeria \\ ${ }^{2}$ Department of Geography, Usmanu Danfodiyo University Sokoto, P.M.B. 2346. Sokoto State, Nigeria \\ ${ }^{3}$ Department of Pure and Industrial Chemistry, Federal University Birnin kebbi, P.M.B 1157, Kebbi State, Nigeria
}

*Corresponding author: Saadu Umar Wali, Department of Geography, Federal University Birnin kebbi, P.M.B 1157. Kebbi State, Nigeria; Email: saadu.wali@fubk. edu.ng

Received: January 04, 2021; Accepted: January 10, 2021; Published: Februay 10, 2021

\begin{abstract}
Detailed knowledge of hydrogeological and hydrochemical characteristics of coastal basins is the prime basis for improved water quality management. This review presents a detailed hydrochemical and hydrogeological reassessment of coastal basins of southwestern Nigeria. Results indicate that the Abeokuta group is the oldest Formation and comprises the Ise, Afowo, and Araromi Formations. Despite the marked spatial variability of these formations, their lithology remains relatively the same. Also crucial in this area is the deltaic Formation, which contains alluvial deposits. The Ogun and Osse-Owena Basins are the central coastal basins in western Nigeria. Though the Osse-Owena Basin has not been fully explored hydrogeologically, it is not associated with good groundwater storage, since basement complex rocks underlie it. These coastal basins were further grouped into the upper surficial aquifer system; and the intermediate aquifer system. Also found in this area is the crystalline Basement Terrain. From the hydrogeologic point of view, unweathered basement rock contains negligible groundwater; though, a significant aquiferous unit can develop within the weathered overburden and fractured bedrock. The general hydrogeological condition in the area showed that groundwater is very localized. These basins' hydrochemistry showed groundwater is relatively good in terms of its suitability for drinking, industrial and agricultural uses. Groundwater classification based on physical parameters showed mixed results, though groundwater sources are most suitable for drinking. Due to the increasing urbanization and other forms of land use in the area, preventive measures must protect groundwater from depletion.
\end{abstract}

Keywords: The Abeokuta Group; The Ilaro Formation; The deltaic formation and alluvial deposits; Hydrogeological condition; Groundwater chemistry

\section{Introduction}

Water is an indispensable prerequisite of life deemed an economic resource rather than a social good [1-4]. Even though freshwater storage in the ecosystem remains steady, freshwater pressure such as subsurface water has experience expansion due to population increase, development, dry season farming, and household activities $[1,5]$. Though, the quality and quantity of this economic resource are likewise critical factors in the perspective of modern water quality management, especially in coastal areas [1,6,7]. Factors such as quality of recharge, rock weathering and mineralogical composition of the underlying rock types, land use, and climate change usually play a vital role in groundwater chemistry, affecting groundwater quality [1,8].Understanding groundwater evolution involves the hydrochemical analyses of major dissolved ions of groundwater, discovering the principal geochemical processes, and evaluating the impacts of land-use types on groundwater quality in various regions of the world $[1,9,10]$. Many factors such as rock-water interactions, climate changes, precipitation or dissolution of mineral species, the intensity of chemical weathering of the different rock types, groundwater resources, exchange reactions, and human activities, prolonged residence time in the aquifer and saltwater intrusion account for the variability of hydrochemistry of groundwater in coastal aquifers [1,11-14]. The hydrochemistry of coastal aquifers of southwestern Nigeria is highly variable due to variation in geological configurations and human activities. Groundwater contamination stemming from human activities, and inadequate sewage discharge is on the rise in Nigeria [15-17]. Consequently, groundwater utilized for domestic uses is problematic and hence calls for scientific scrutiny. Examining hydrochemistry and groundwater quality in coastal regions is crucial to monitor and detect groundwater contaminants sources [18-21]. Groundwater quality analysis in Abeokuta South, Nigeria by Emenike, Nnaji [17] showed that water quality parameters exhibited wide variations from location to location. Sodium, magnesium, iron (++), and EC showed the most violation of drinking water quality standards. Anthropogenetic actions are escalating threat to groundwater quality and thus call for routine monitoring of groundwater in Abeokuta. Statistical and hydrochemical modelling of groundwater quality southwestern Nigeria showed a conjunctive imprint of anthropogenic and geogenic activities influencing the increasing dissolved chemical constituents in the groundwaters 
[1]. Hydrochemical analysis of groundwater quality along the coastal aquifers of southwestern Nigeria revealed that the primary process influencing the hydrochemistry is saltwater invasion while mineral dissolution and rainwater infiltration play less significant roles [22]. Nitrate controls biogeochemical process over Fe, and its concentrations are above the World Health Organization's (WHO) standard for drinking water in most water samples in the Shallow Coastal Aquifer of Eastern Dahomey Basin, Southwestern Nigeria [8]. Integrated geophysical and geochemical investigations of saline water intrusion in a coastal alluvial terrain of southwestern Nigeria by Oyeyemi, Aizebeokhai [23], showed a lateral invasion and up coning of saline water within the aquifer systems. The water is alkaline, and salinity is high with a very high electrical conductivity. The impact of anthropogenic activities over groundwater quality of a coastal aquifer in Southwestern Nigeria indicated some metals such as $\mathrm{Cu}, \mathrm{Fe}, \mathrm{Mn}$, $\mathrm{Al}, \mathrm{Zn}, \mathrm{Pb}, \mathrm{As}, \mathrm{Cd}, \mathrm{Cr}$ and $\mathrm{H} 2 \mathrm{~S}$ ) were detected in only some shallow wells. However, the effects on public health are still undocumented. The drainage, geology, chemistry and associated human factors play a vital role in the extent of shallow groundwater contamination in the area [24]. Potential sources of contaminants to the groundwater such as weathering of bedrocks, leachate from septic tanks and dumpsites, runoff of materials, hardness, nutrients from agricultural lands, and chlorine pollution were identified in basement rocks of Osun State, Southwest, Nigeria [25]. Groundwater in Abeokuta Southwestern, Nigeria, is not suitable for drinking but has good irrigation quality [26]. Assessment of the risks of groundwater pollution in the coastal areas of Lagos, southwestern Nigeria, showed that the lower aquifer is mostly affected with saline water intrusion while the phreatic aquifer pollutions are both from anthropogenic and saline sources [27]. While the hydrochemistry of coastal aquifers is well researched, studies combining the hydrogeological and hydrochemical analysis of groundwater are rare. This review presents a detailed hydrogeological and hydrochemical analysis of coastal basins of southwestern Nigeria.

\section{Geographical Setting}

Southwestern Nigeria's coastal basins constitute the Benin Embayment's eastern portion, forming an arcuate coastal basin [2830]. The onshore parts underlie the coastal plains of southwestern Nigeria, Benin, and Togo [31]. The Okitipupa Basement Ridge separated the Benue Trough's embayment until the CampanianMaastrichtian period when subsidence and marine transgression united the two basins (Figure 1). Some basement chunks that underlie the Dahomey Embayment are displaced towards the basin's northern and southern axis and the offshore [31]. An inventory of water resources in southwestern Nigeria confirms that water supplies are generally from surface sources, such as dams and weirs in streams and rivers. Borehole and shallow-wells, tapping groundwater, are used to complement the short supply from surface water. Existing data from UNICEF-water assisted projects suggests that boreholes in southwestern Nigeria are intended to tap water from the weathered regolith or the jointed/fractured basement rock aquifers. The Coastal Basins are comprising of the Osse, Ogun and Yewa River Basins.

These basins are grouped as the geological formations outcrop parallel to each other in an east-west direction and transgressing the basins in the same Coastal River Basins. The Osse River Basin is about $51400 \mathrm{sqkm}$ in landmass. On the other hand, the Ogun River Basin has about occupied an area of about $88800 \mathrm{sqkm}$. The two basins are drained by many dendritic flowing streams, which empty their water into the sea. The Osse Basin is perhaps the lateral equivalent of the Benin-Owena River Basin [32]. The main drainage in the Osse-Osiomo systems is little streams and rivulets flowing straight into the sea and forming part of the Delta composite. Parallel streams with the same pattern drained the Ogun Basin, most protuberant being the Ogun, Osun, and Yewa river systems. This basin's climate is archetypally coastal with very high rainfall, ranging from $2250 \mathrm{~mm}$ in the north to over $2600 \mathrm{~mm}$ along the coastal line. The relative humidity is very high, $>80 \%$. The mean annual temperature is about $21^{\circ} \mathrm{C}[32]$.

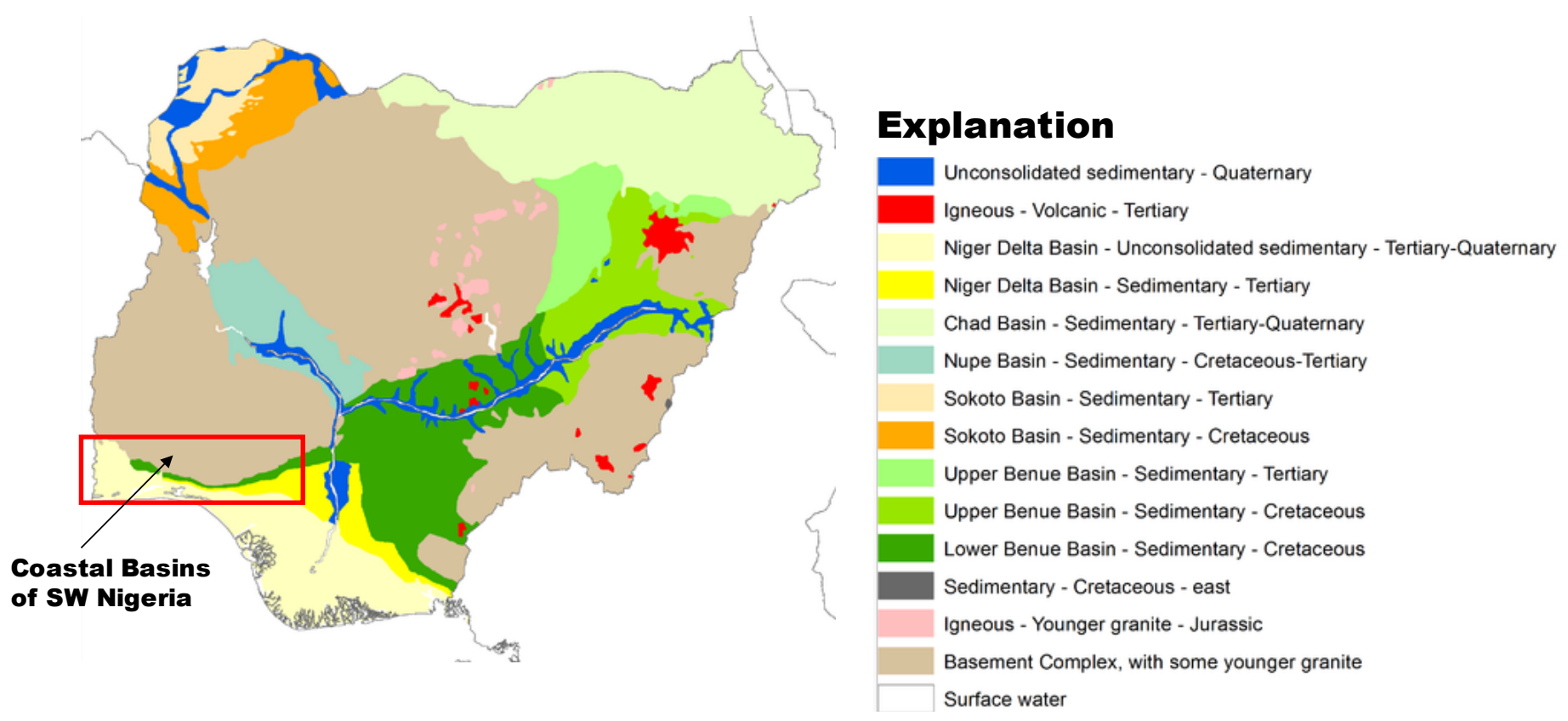

Figure 1: Coastal Basins of Southwestern Nigeria. After Ola-Buraimo, Oluwajana [31]. 


\section{Geological Setting}

The coastal basin of southwestern Nigeria is restricted to the west by the Ghana ridge, which is an extension of the Romanche Fracture Zone; and eastwards, by the Benin Hinge line, a basement escarpment which splits the Okitipupa Structure from the Niger Delta Basin and also marks the inland extension of the Chain Fracture Zone (Figure 2). The Nigeria portion of the basin spreads from Nigeria's boundary and Benin's Republic to the Benin Hinge Line. The stratigraphy of the sediments in the Nigerian sector of the Benin Basin is contentious. Different stratigraphic names have been suggested for the same Formation in different localities within the basin [31]. This problem can be attributed to the lack of adequate borehole reporting and satisfactory outcrops for comprehensive stratigraphic studies. As a result, the stratigraphy of the entire basin was divided into three chronostratigraphic compendia. These are (i) pre-lower Cretaceous folded sediments and (ii) Cretaceous sediments and Tertiary sediments (Figure 3).

In the Nigerian sector of the basin the Cretaceous sequence, as compiled from outcrop and borehole records, consists of the Abeokuta Group, further divided into three geologic units: Ise, Afowo, and Araromi Formations. Ise Formation overlies the basement complex unconformably and comprises of coarse conglomeratic sediments $[33,34]$. Afowo Formation is composed of transitional to marine sands and sandstone with variable but thick interbedded shales and siltstone $[35,36]$. Araromi is the uppermost Formation and comprises shales and siltstone with interbeds of limestone and sands. The Tertiary sediments comprise Ewekoro, Akinbo, Oshosun, Ilaro, and Benin (bare coastal sand). The Ewekoro Formation comprises fossiliferous, well-bedded limestone while Akinbo and Oshosun Formations are made up of flaggy grey and black shales [37,38]. Glauconitic

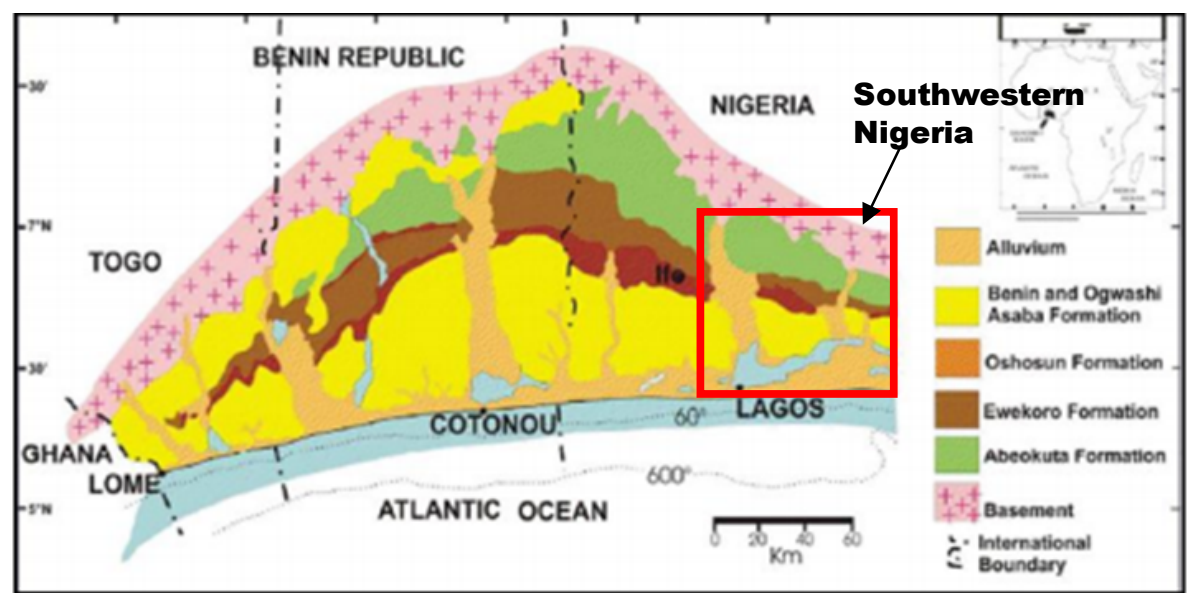

Figure 2: The Nigerian portion of Dahomey (Benin) Basin. After Ola-Buraimo, Oluwajana [31].

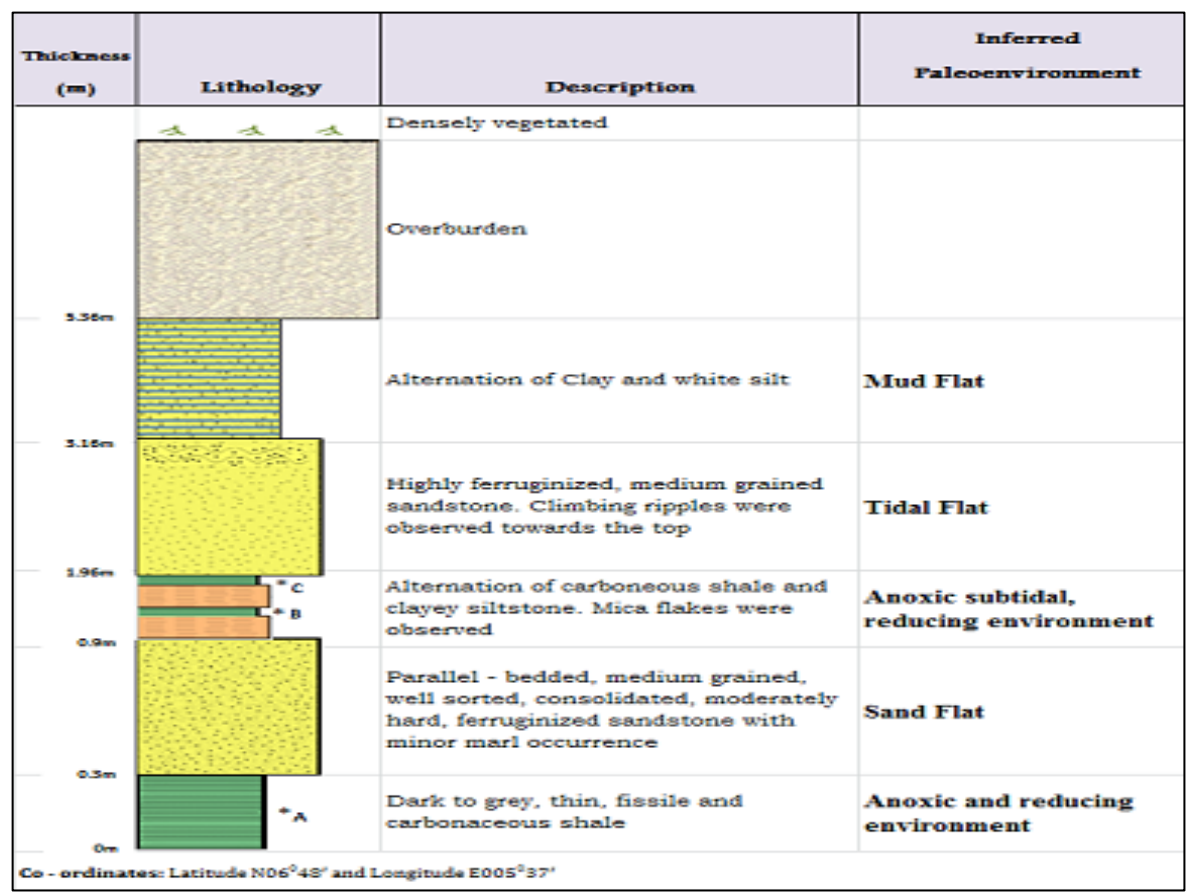

Figure 3: A Lithologic section of Arimogija - Okeluse exposure. After Ola-Buraimo, Oluwajana [31]. 
rock bands and phosphatic beds define the boundary between the Ewekoro and Akinbo Formations. The Ilaro and Benin Formations are predominantly coarse sandy estuarine, deltaic, and continental beds [31].

\section{The Abeokuta Group}

The sedimentary Formation of southwestern Nigeria, otherwise known as the Eastern Dahomey Basin, extending from the Nigeria/ Benin border in the west of Makun-Omi and broken in the east. The Abeokuta Group is the oldest Formation, and it comprises of main sands with intercalations of argillaceous sediments, which lie unconformably on the crystalline basement complex formation $[39,40]$. This group can be subdivided into three geologic units;

- The lse Formation, which overlies the basement complex and consists of pre-drift sediments of grits and siltstones and overlain by coarse-medium grained, loose sands interbedded generally by kaolinitic clays;

- The Afowo Formation comprises intermediate to marine sands and sandstone with variable but thick interbedded shales and siltstones. The shale to sand ratio Increase upwards with the sediment becoming highly fossiliferous. The whole arrangement represents paralic sedimentation; and

- The Araromi Formation, which is the youngest of the stratigraphic sequence, comprises shales and siltstones with Interbeds of limestone and sands. It Is opulently fossiliferous.

The Abeokuta Formation usually has a basal conglomerate with about 1 meter thick and mostly comprises poorly rounded quartz pebbles with a silicified and ferruginous sandstone matrix or a soft gritty white clay matrix [39]. The formation outcrops where there is no conglomerate, a coarse, poorly sorted pebbly sandstone with copious white clay establishes the basal bed. The superimposing sands are coarse-grained, clayey, micaceous, and ill-sorted, suggestive short distances of transportation, or short duration of weathering and possible derivation from the granitic rocks located to the northwards. Upward stratigraphically along with the outcrop areas, the shale content increases progressively in some places, particularly around Ijebu-Ode. Close to the embayment's eastern margin, thin beds of lignite may be present together with a high impregnation of bitumen in the sand and clays. These features are displayed in most of the eastern part of the embayment, locally referred to as Tar sand. The basal beds' upper horizons were found in some outcrops to contain thin beds of Oolitic ironstone. The stratigraphic dating from palynological studies indicates that the ages of the lower and upper limits of the neostratotype Formation are late Albian and late Senonian. This is a characteristic species for the late Turonian-early Senonian of the Ivory Coast and was reported from Gabon's Coniacian-Campanian. Therefore, this pollen occurrence implies a late Senonian age for the Formation's upper layers [39].

\section{The Ise-Afowo, Araromi, Akinbo, and Ilaro Formations}

Ise and Afowo Formations are similar; thus, the two geologic units are treated together in most literature $[39,41,42]$. The two formations contain sand and sandstones, but the latter is interbedded by thick of shale units. Similarly, the Ise, Afowo, and Abeokuta Formations showed a similar lithologic and electric log. The uppermost beds of Abeokuta Formation which outcrop in the Ijebu-Ode, Itori, Wasimi, and Ishaga, consist mainly of fine-coarse-grained sand which is occasionally interbedded by shale, mudstone, limestone, and silt. In most recent literature the Ise and Afowo Formations are discussed as Abeokuta Formation. The Abeokuta Formation consists mainly of grits, loose sand, sandstone, kaolinitic clay, and shale. It was further characterized as usually having a basal conglomerate or a basal ferruginised sandstone [39]. The Araromi Formation overlies the Afowo Formation and has been described as the youngest Cretaceous sediment in the eastern Dahomey Basin. It is composed of fine to medium-grained sandstone at the base, overlain by shales, siltstone with interbedded limestone, marl, and lignite. This Formation is highly fossiliferous [43]. The Ewekoro Formation overlies the Araromi Formation. It is an extensive limestone body, which is traceable over a distance of about $320 \mathrm{~km}$ from Ghana in the west, towards the eastern margin of the Dahomey (Benin) Basin in Nigeria [44,45]. It is Palaeocene in age. Superimposing the Ewekoro Formation is the Akinbo Formation, which is mainly composed of shale and clayey sequence. The clay stones are concretionary and are largely kaolinite. The Formation's base is defined by the presence of a glauconitic band with lenses of limestones [43]. The Akinbo Formation and consists of greenish-grey or beige clay and shale with interbeds of sandstones. The shale is thickly laminated and glauconitic. The basal beds may consist of either, sandstones, mudstones, claystones, clay-shale, or shale. The Ilaro Formation superimposes the Oshosun Formation and consists of massive, yellowish poorly, consolidated, cross-bedded sandstones. The youngest stratigraphic sequence in this basin is the Benin Formation, otherwise known as the Coastal Plain Sands and contains poorly sorted sands with layers of clay units. The sands are occasionally interbedded and show transitional to continental characteristics. The age is from Oligocene to Recent [43]. Most of the boreholes constructed in the basin are either single-screened or multiple-screened and occasionally open wells are constructed through fractured basement rocks that produce a considerable amount of water. The Depth to water level hardly exceeds 24 meters. Most aquifers in this basin are found around 40 meters below the surface. These aquifers are rarely confined, and very few boreholes tap water below 60 meters [46]. The mean yield from boreholes is $\sim 0.4 \mathrm{l} / \mathrm{s}$. In the crystalline basement section of the basin, a borehole depth of $40-80 \mathrm{~m}$ is estimated. Data from available boreholes in the southern end of Kwara State extending to Osun State, indicate the range between 25-68 meters borehole depth. The overburden thickness is also highly variable, ranging between 3-24 meters. In places around Ibadan, the overburden thickness and borehole depth are within the same range. The thickness of the overburden aquifer in the rural areas of Oyo State is correlated to the tectonic fractures rather than weathering (regolith).

Borehole yield ranging from 1-2 l/s in the basement complex section is considered suitable for installing motorized submersible pumps. Borehole yields less than $0.5 \mathrm{l} / \mathrm{s}$ are also considered good for handpumps. The recharge into the weathered aquifer is predominantly through the infiltration of rainwater. Therefore, continued yields from motorized pumps may not be workable. Midwestern Nigeria’s 
coastal basin's principal aquifers occur in sandy units and overburden/ superficial deposits confined by shale and clay formations. The aquifers' thickness is highly variable with first and third horizons reaching a thickness of about 200 meters and 250 meters at Lekki headland. The second horizon is roughly 100 meters thick (Figure 4). The estimated groundwater stored in the first aquifer horizon is about $2.87 \times 103 \mathrm{~m}^{3}$. The water table is mostly shallow, ranging $0.4-21$ meters below the ground surface. It is estimated that annual fluctuation is less than 5 meters. The principal aquifer is within bare coastal sands, occasionally underlain by impermeable horizons of shale and clay units. Many high-yielding boreholes provide more than $30 \%$ of the water supply in Lagos and its hinterlands [46].

Table 1: Hydrogeology of coastal basins of southwestern Nigeria.

\begin{tabular}{|l|l|l|}
\hline \multicolumn{1}{|c}{ Age } & \multicolumn{1}{c}{ Ogun RIver Basin } & \multicolumn{1}{c|}{ Owena Basin } \\
\hline Quatemary & $\begin{array}{l}\text { Deltaic Plains } \\
\text { Benin Formation }\end{array}$ & $\begin{array}{l}\text { Deltaic Plains } \\
\text { Benin Fomation }\end{array}$ \\
\hline Tertiary & $\begin{array}{l}\text { Ilaro Fomation } \\
\text { OshosunFomation } \\
\text { Eweloro Formation }\end{array}$ & $\begin{array}{l}\text { Ameld Formation } \\
\text { Imo S hale }\end{array}$ \\
\hline Cretaceous & $\begin{array}{l}\text { Abeoluta Formation } \\
\text { Basement Complex }\end{array}$ & Basement Complex \\
\hline
\end{tabular}

After Offodile [32].
The geological succession in these basins simple, forming a simple monocline against the basement outcrop northward, with a slight faulting indication. The inclines are reportedly about $1^{\circ}$ or less southwestwards (Table 1). The Basement Complex rocks superimpose more than $50 \%$ of the Coastal basins [ $47-49$ ]. The Abeokuta Formation is the oldest outcropping sedimentary formation in the Ogun and Osse River Basin. This appeared to cover the basement complex directly. The Formation is in turn superimposed by the Ewekoro, Ilaro, and Benin Formations. The is the substantial development of alluvium in the coastal areas and along the course of the major drainage systems of the Rivers Ogun and Osse.

\section{The Abeokuta Formation}

This is the oldest Formation in the Ogun Basin, outwardly covering the Basement Complex. The Formation thickness ranged from 250 to 300 meters, containing arkosic sandstones and grits, tending to be carbonaceous towards the bottom. There is an increase in thickness from about 250 meters in the western sections of the basin towards the Benin border. The basal conglomerates also were encountered. One of the outcrops gave the following units in Figure 5. The Abeokuta Formation has good potential for groundwater except that the bituminous constituents associated with the sands could affect groundwater quality. This Formation is being interrelated to the Nkporo Shale, east of the River Niger. The little report is existing

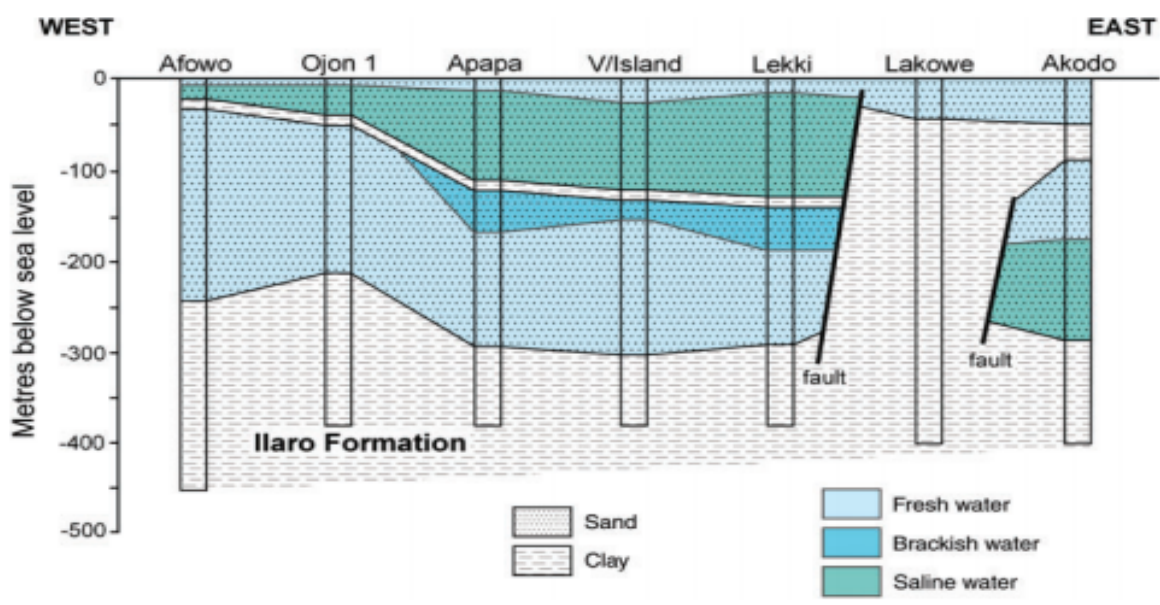

Figure 4: Typical hydrogeological section of coastal basins of southwestern Nigeria. After Adelana, Vrbka [46].

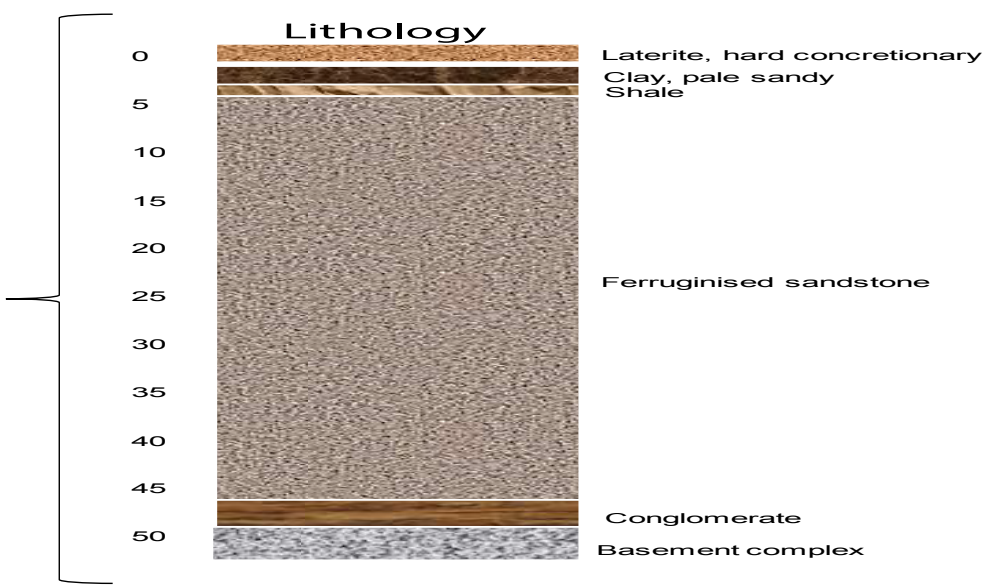

Figure 5: Section of Abeokuta Formation. After Offodile [32]. 
about the groundwater potentials of the Abeokuta Formation. Nevertheless, its proximity to the Basement Complex and its high porosity, a substantial amount of groundwater is expected to be stored above the crystalline rock layer. This condition has been confirmed at the bottom near the Basement layer, intercepted by the borehole described in the following section. This Formation is outstanding in the basin. Hydrogeologically, groundwater in the basin's northern parts is limited to the splintered and in-situ worn portions of the rocks. The in-situ worn portion either superimposes the unweathered basement or occurs within the unweathered basement [50].

In the former, the worn materials create phreatic aquifers typically exploited through hand-dug shallow wells, while in the later, groundwater is confined in nature and can only be accessed through boreholes. Groundwater flow is strongly influenced by topography and two common types of springs, mainly, overland and slope springs have been observed in the area. Recharge to these aquifers is primarily by infiltrating rainfall and in some places, by the outflow from adjacent surface water. The recharge areas comprise decayed and splintered rocks in which pressure heads quickly spread through local waterbearing fractures and unified voids, thereby leading to an abrupt rise in ejections in response to rain. Spring discharges in the northern parts of the basin are very common in the rainy season but terminate totally during the dry season. The area underlain by sedimentary formations is regarded as having good groundwater potential due to an aquiferous sandy layer [50].

However, the success of boreholes in this basin is highly variable, and it could be credited to inferior drilling methods, or the frequent occurrence of the clayey matrix, which extends to seal the pores and reduce the absorptivity. The successful boreholes were reported from Aiyetoro and Ijebu Ode. Also, specific capacity ranging from 63 to $17550 \mathrm{list} / \mathrm{hr} / \mathrm{m}$ (1300 gift) have been measured. Successful boreholes were also reported from Iboro, Imushin, and Ishaga as depicted below. In the eastern parts, within the Osse Basin, the Abeokuta Formation appears to thicken in Agenebode and Auchi's higher regions, where the groundwater table is deep (120-300 meters). The low water table recorded is thought to be due to the aquifer's high porosity, as typified in by the Kerri-Kerri Formation, in the Upper Benue Basin Nanka Sands of the Anambra Basin [32]. Some drilled boreholes in the Abeokuta Basin are shown in Figure 6. Figure 7 illustrates some successful boreholes in Abeokuta Formation. The GSN. BH. No. 2436 is located at Meko. The lies unconformably showed unconformity. It has a total depth of 57.9 meters. Although it penetrates the Basement Complex, yields are relatively low (1620 lits/hr (0.45 lits/sec)-the GSN. BH. No. 2612 was located at Igbogila. The borehole penetrates a Basement Complex section and has a total depth of 70.5 meters. Yield is relatively high ( $28350 \mathrm{lits} / \mathrm{hr})$, or $7.87 \mathrm{lits} / \mathrm{sec}$. it has a specific capacity of about 390.8 lits/hr-the GSN. BH. No. 2438 is located at Aiyetoro. The borehole penetrated a Basement Complex formation and showed unconformity. The total depth is about 55.9 meters. Yield is relatively low (2340 lit/hr), or 0.65 lits/sec (Offodile, 2002). Figure 7 further illustrates some boreholes penetrating the Abeokuta Formation. The GSN. BH. No. 2433 reached a depth of 48 meters below the ground level. This borehole's actual location is unknown, but it is believed to penetrate the Abeokuta Formation. The borehole produced a yield of about $3600 \mathrm{lits} / \mathrm{hr}$ and had a specific capacity of $11880 \mathrm{lit} / \mathrm{hr} / \mathrm{m}$ (Offodile, 2002). The GSN. BH. No. 2435 is located at Ishaga. It penetrated the basement complex (BC) and had a total depth of 75 meters. It had a yield of 31050 lits/hr. It also had a specific capacity of $3192.75 \mathrm{lit} / \mathrm{hr} / \mathrm{m}$ [32]. The lithology is mainly sandy (Figure 7) - the GSN. BH. No. 2597 is located at Ijebu Ode about $46 \mathrm{~km} \mathrm{NE}$ of the town. The borehole penetrated the BC and reached a depth of 54.6 meters. The yield obtained from this well is comparatively low (10800 lits/hr), with a specific capacity of $935.5 \mathrm{lits} / \mathrm{hr} / \mathrm{m}$. The last borehole in
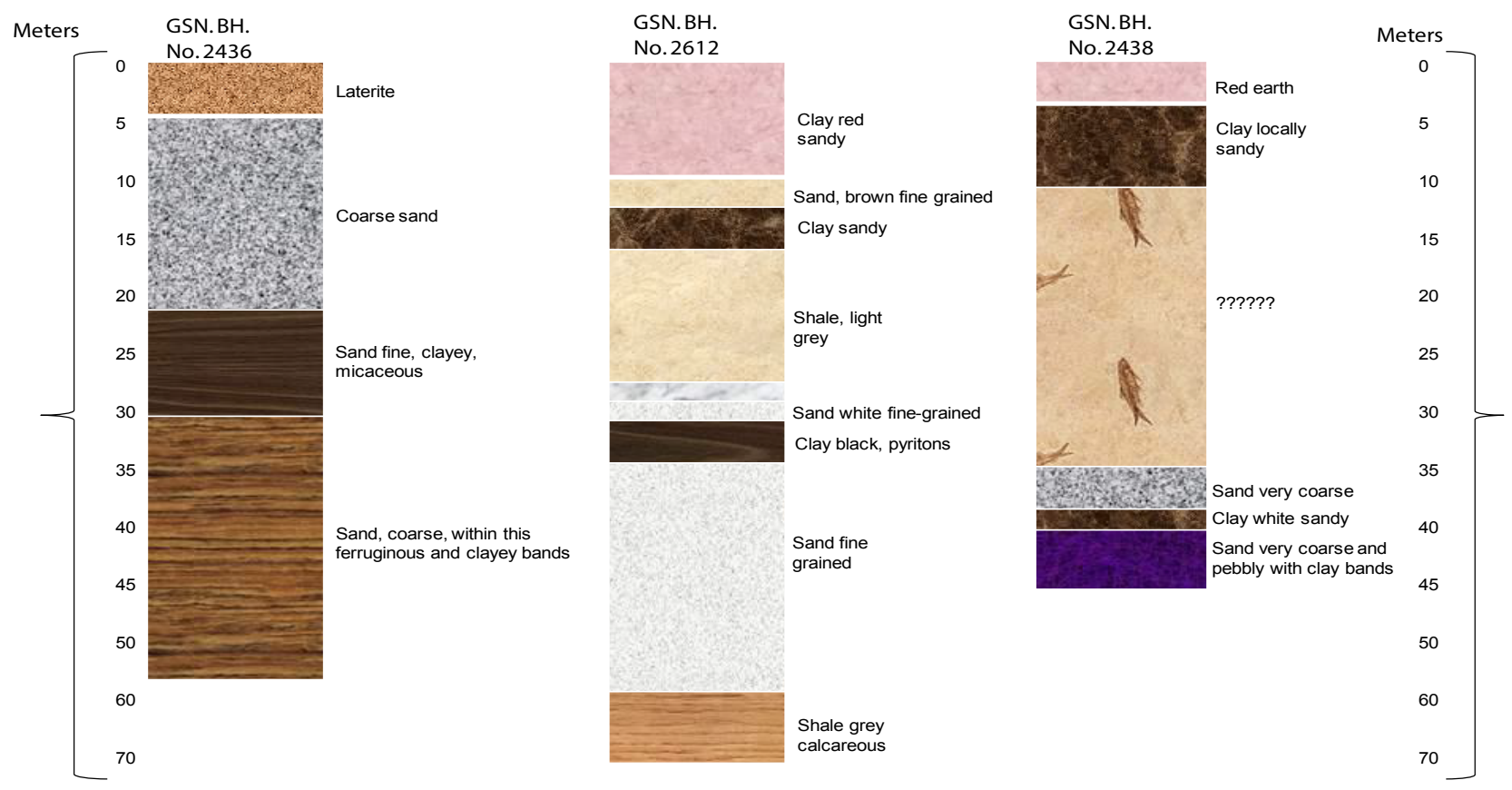

Figure 6: Lithological sections of boreholes in Abeokuta Formation. After Offodile [32]. 

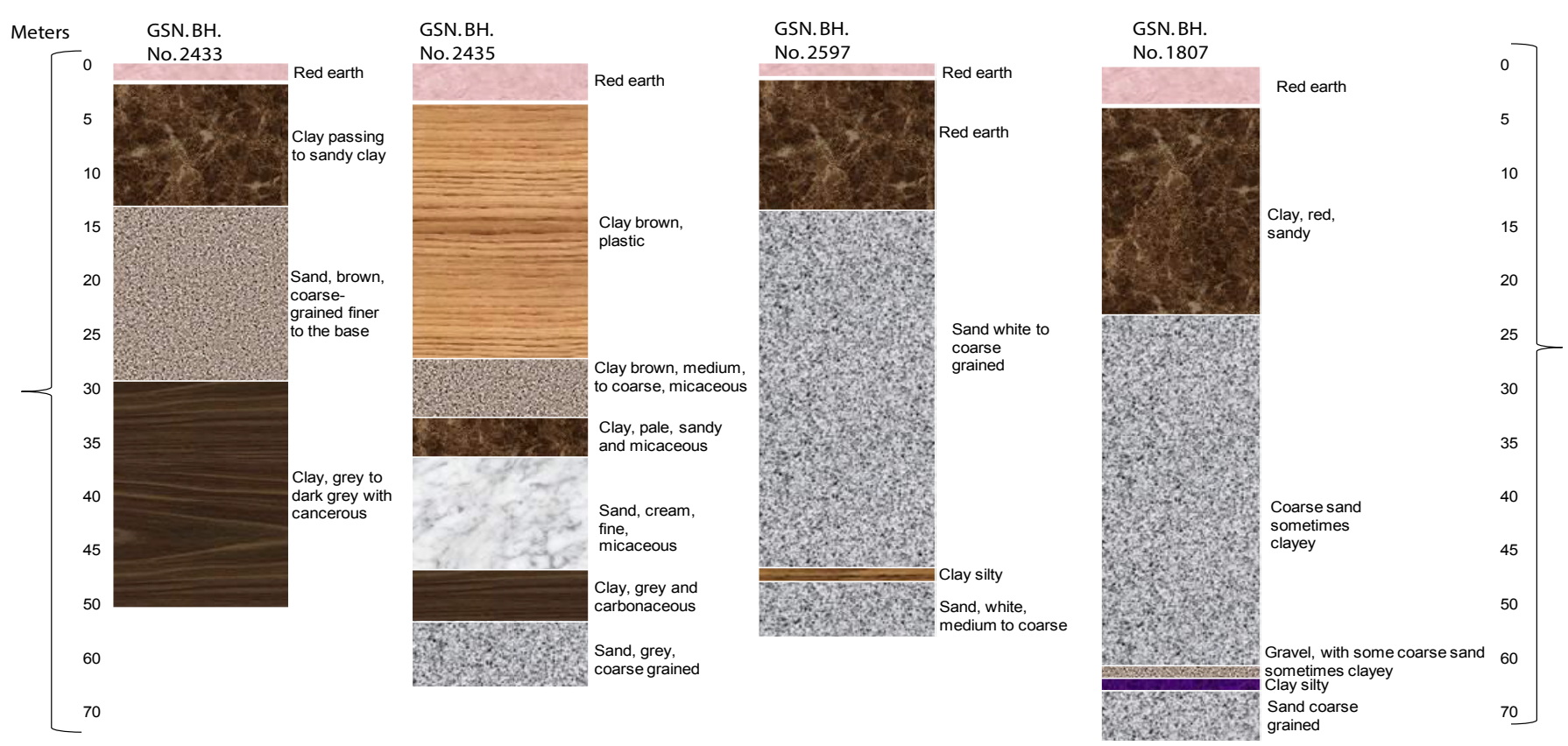

Figure 7: The lithology of boreholes in Abeokuta Formation. After Offodile [32].

Figure 6 (GSN. BH. No. 1807), also lies unconformably on the BC. The well reached a depth of 72.8 meters and produced a yield of 13500 lits/ $\mathrm{hr}$, with a specific capacity of $4039.2 \mathrm{lit} / \mathrm{hr} / \mathrm{m}$ [32]. Generally, boreholes penetrating the Abeokuta Formation has a higher proportion of sands.

\section{The Ilaro Formation}

The Ilaro Formation is comprised of fine to medium-grained which are reasonably well sorted. The Formation lies conformably on the Oshoshun Formation (Lower-Middle Eocene) and locally unconformably underneath the Benin Formation -OligocenePleistocene [51-53]. The Ilaro Formation is typically Middle to Upper Eocene in age. The estimated thickness of this Formation is about 70 meters and displays rapid lateral facies changes. This can affect aquifer quality [54]. Hydrogeologically, not much information exists on the
Ilaro Formation, though it is reported to be transitional to, and in part equivalent to the Ameki Formation. Given the Ilaro Formation's geological physiognomies, its equivalent lateral part could be a good aquifer that can yield a substantial amount of water. However, GSN. BH. No. 2611 in Ilaro had reached a depth of 57 meters and gave a low yield of 2975 lits/hr and a specific capacity of $1023 \mathrm{lits} / \mathrm{hr} / \mathrm{m}$ [32]. The lithology of this borehole is illustrated in Figure 8.

\section{The Benin Formation}

The Benin Formation (Miocene-Recent) consists of thick bodies of ferruginous and white sands. The Formation lies conformably on Ilaro Formation. Friable, poorly sorted with intercalation of shale, clay, and sandy clay with lignite [55]. The Benin aquifer is an important reservoir of groundwater. It is well developed in the Osse

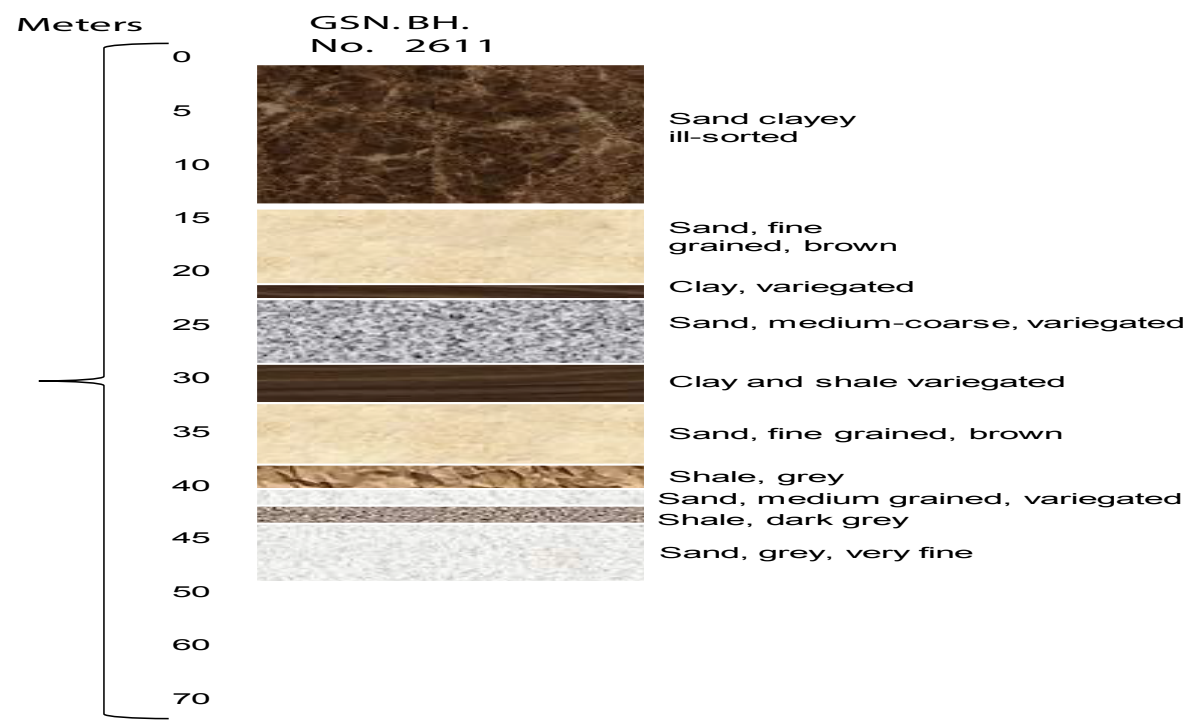

Figure 8: The lithology of the borehole in Ilaro. After Offodile [32]. 
Basin and underlies more than $50 \%$ of its sedimentary section. The Benin aquifer is underlain by the sandstones of and shales of the upper Ilaro Formation, consists of a sequence of predominant continental sands and some lenses of shales and clays proved to be up to 107.7 meters thick in the area. The cross-section of the Benin Basin is further illustrated below. The Benin Aquifer gives very high yields of up to 4500 lits $/ \mathrm{hr}(10000 \mathrm{~g} / \mathrm{hr})$ in most parts of the outcrop area.

The water table is relatively shallow, ranging between 20 to 25 meters. The water quality is also good. By this Formation, the land area underlain extends from Ado-Odo, Ilaro, Ikeja, and Mushin, passing through Okitipupa of Ogun Basin, into a broad area BeninUgheli-Agbo province of Osse Basin, in Edo and Delta States [32]. The lithology of boreholes from the Benin formation is illustrated in Figure 8. The GSN. BH. No. 2608 is located at Ikeja, had a total depth of 99 meters. The yield from this borehole is comparatively high (55350 lits/ hr) [32]. Figure 9 illustrates the lithology of Benin formation [56].

Figure 10 shows the specific capacity of this borehole is 9,220 lits $/ \mathrm{hr} / \mathrm{m}$. This well penetrates the Benin Formation. The GSN. BH. No. 927 is located in Otta. The well had a depth of 243 meters. The remaining lithologies were not accessed. Yield from this borehole was estimated to be 22500 lits/hr in GSN. BH. No. 2599, located at Mushin penetrates a similar sequence, attained a depth of 108.6 meters. This well gave a yield of $32850 \mathrm{lits} / \mathrm{hr}$ (9 lits/sec). The specific capacity was 1930.5 lits $/ \mathrm{hr} / \mathrm{m}$. This prolific yield is typical of the Benin Formation across the southwestern river basins of Nigeria. The Benin Formation is also very important in the Osse Owena Basin, where it is the primary groundwater source [32].

\section{The Deltaic Formation and Alluvial Deposits}

This Formation contains alluvial deposits associated with Lagos' coastal areas and the Osse Basin areas connecting to the Niger Delta Basin [57-59]. The hydrogeological conditions in areas were explained in studies on the Niger Delta Basin. Be sufficient to mention that the sandstone beds are limited in thickness and usually variable in the lateral extent. Furthermore, these aquifers have been exposed to saline water intrusion due to overdevelopment and seawater invasions. Correspondingly, the limitations in thickness and extent of the aquifers significantly reduce the boreholes' specific capacity. The groundwater condition varies swiftly across the basins. In the Lagos region areas where the Formation appears to be least developed and has been polluted, the underlying Benin Formation provides a ready supply to the groundwater demand in the basin [32]. These comprise the Yewa, Ogun, and Oshun river networks' vast basins, presenting a

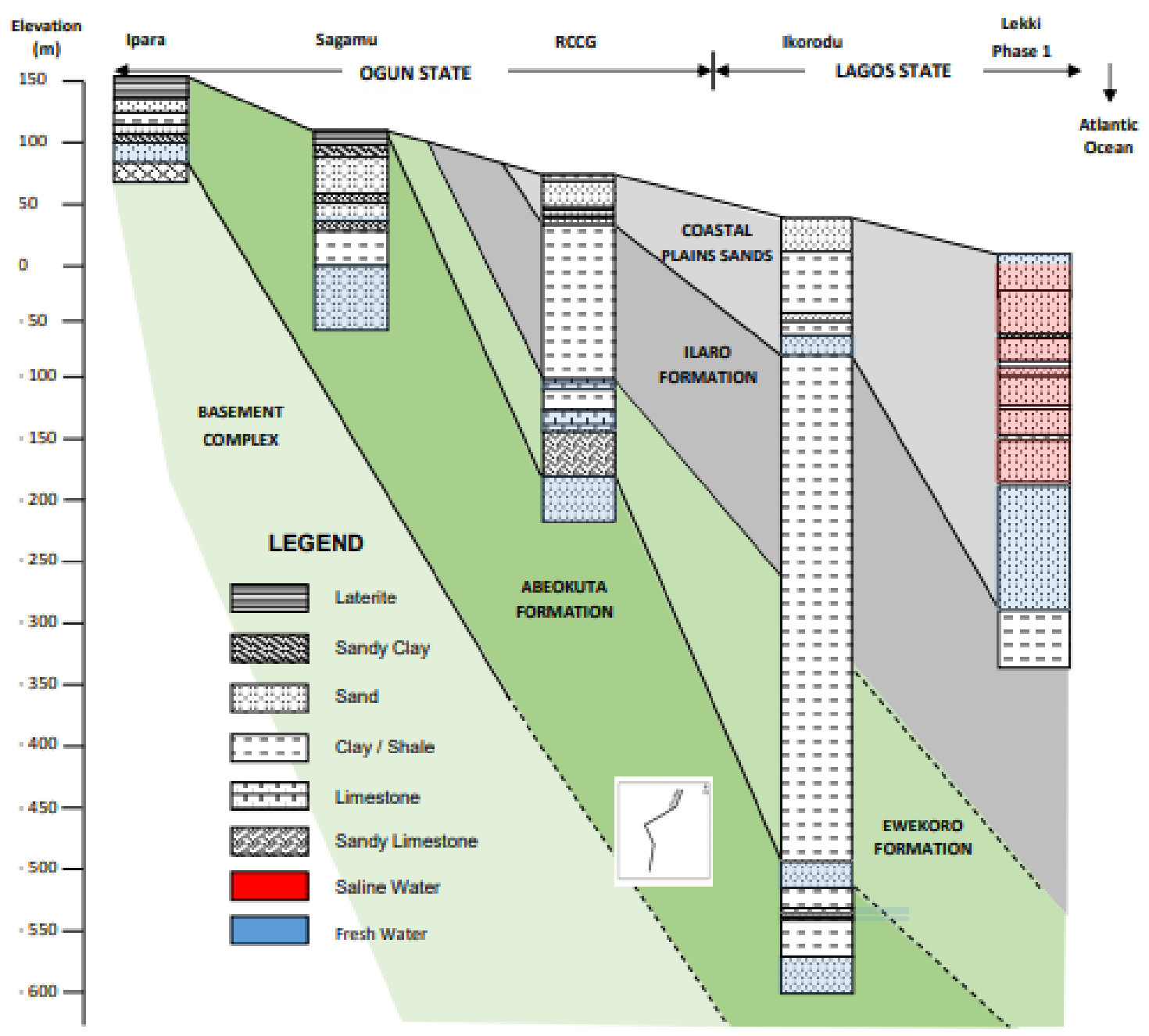

Figure 9: Hydrogeologic Cross-section of the Benin Basin. After Oteri and Ayeni [56]. 




Figure 10: The lithology of the borehole in Ikeja and Otta. After Offodile [32].

general alluvial development with considerable groundwater potential. The available drilling records have not distinguished this Formation. However, a 49275 lits/hr yield from GSN. BH. No. 2610 at Ibefun. The borehole was just 28.5 meters deep and had a specific capacity of 9234 lits $/ \mathrm{hr} / \mathrm{m}$. This presents an excellent yield and underlines the high potential of these river basins' alluvial deposits. The hydrogeology of these basins is similar to that of the Niger Delta Basin, discussed in the previous chapter.

\section{Hydrogeological Condition in Coastal Basins of Southwestern Nigeria}

\section{The Ogun River Basin}

The Ogun River Basin is one of the significant coastal basins located in southwestern Nigeria [60-62]. The basin is situated between latitudes $6^{\circ} 26^{\prime} \mathrm{N}$ and $9^{\circ} 10^{\prime} \mathrm{N}$ and longitudes $2^{\circ} 28^{\prime} \mathrm{E}$ and $4^{\circ} 8^{\prime} \mathrm{E}$ (Figure 11). About $98 \%$ of the basin area falls within Nigeria and the remaining $2 \%$ in the Benin Republic. The basin covers an of about 23,000 sqkm. The topography is generally low, with the gradient in the north-south direction. The Basin is drained by the Ogun River which had its source from the Iran hills at an elevation of about 530 meters above sea level. The river flows southwards over a distance of about $480 \mathrm{~km}$ before it discharges into the Lagos lagoon. The main tributaries of the Ogun River are the Ofiki and Opeki Rivers. Two seasons are distinguishable in the Ogun River Basin; a dry season from November to March and a wet season between April and October. The mean annual rainfall ranged from $900 \mathrm{~mm}$ in the northern parts to $2000 \mathrm{~mm}$ in the south. The total annual potential evapotranspiration ranged from 1600 and $1900 \mathrm{~mm}$ [63]. Hydrogeologically, very little is known about the Ogun
Basin since the basin is often discussed in southwestern Nigeria's coastal basins. However, Offodile [32], compiled data on borehole on borehole depths summarized in Table 2 . There is not much reporting of hydrogeological physiognomies of the individual boreholes from western Nigeria's coastal basins. Most of the boreholes in this basin penetrate the Pre Cambrian-Basement Complex. Yields from these boreholes are poorly known. However, GSN. BH. No. 2614 in Ewekoro gave an artesian flow of 90-135 lits/hr obtained near the borehole base. Similarly, GSN. BH. No. 1583 at Itori gave artesian flow at 81 meters. The estimated yield was 450 lits/hr and a specific capacity of $92.7 \mathrm{~m}$ $45000 \mathrm{lits} / \mathrm{hr} / \mathrm{m}$. Although, these two boreholes produced a substantial amount of water, a more detailed study on the hydrogeology Ogun Basin is required for further evaluation.

\section{The Osse Owena Basin}

Also known as the Benin-Owena, River Basin occurs in Edo-State. The basin is situated within the Western Littoral Hydrological Area HA6 , one of the eight hydrological areas into which Nigeria is subdivided. The gauge station at which the hydrometric measurements were made is located at Osse River at Iguoriahki [64-66]. Hydrogeologically, this basin has not been well explored. Earlier, Offodile [32] summarised borehole information on this basin. Base on the borehole information presented in Table 3, it is clear that this basin has not been fully explored hydrogeologically.

\section{The Osun River Basin}

The Osun basin is drained by the Osun River system which rises from Oke-Mesi ridge, about $5 \mathrm{~km}$ North of Effon Alaiye along the Oshun and Ekiti States border and flows North through the Itawure 


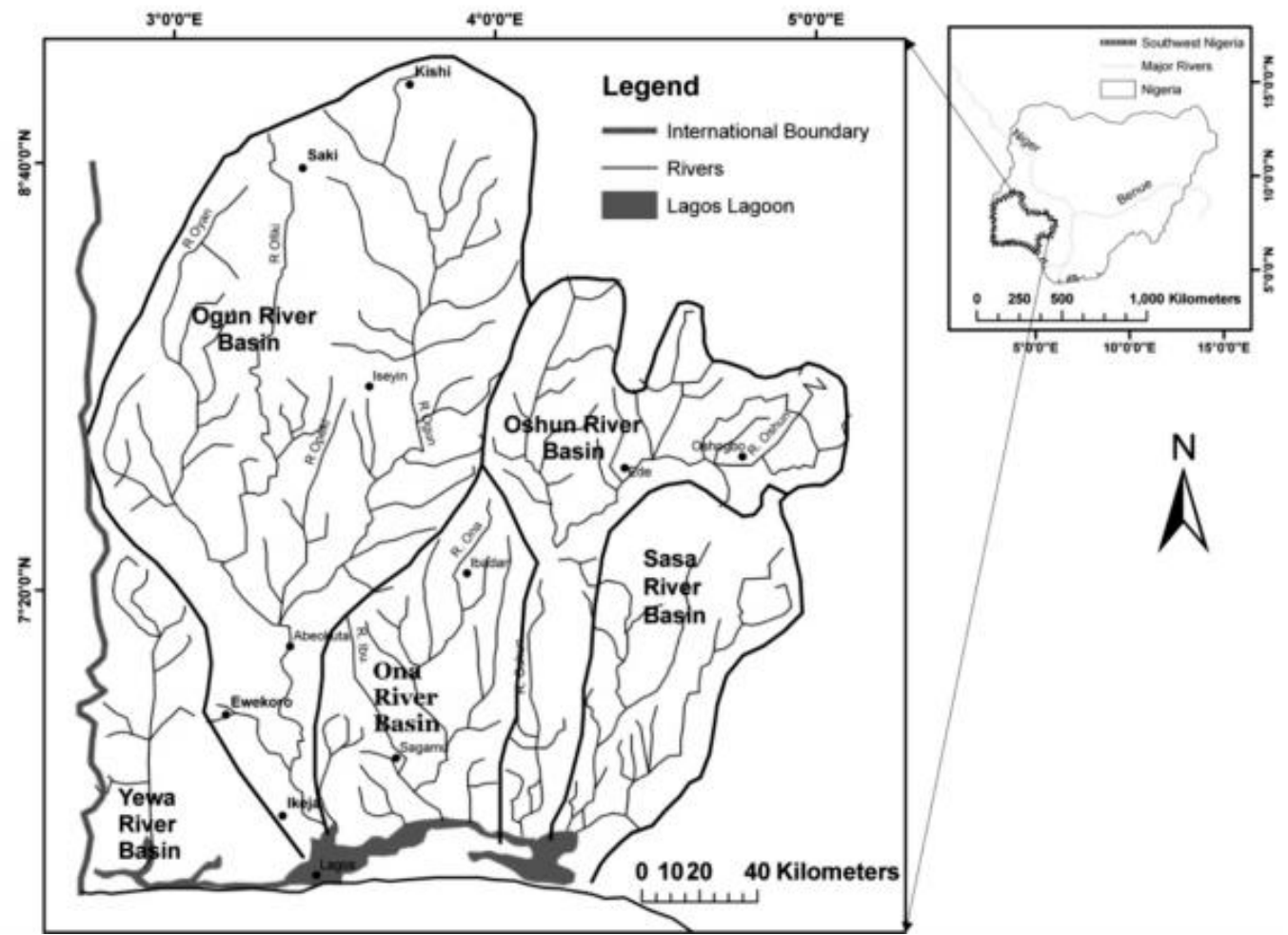

Figure 11: Ogun-Osun River Basins and the Adjacent Basins. After Oke, Martins [63].

Table 2: Borehole information from Ogun Basin.

\begin{tabular}{|c|c|c|c|c|c|c|c|c|c|}
\hline S/no. & $\begin{array}{c}\text { Borehole Locality } \\
\text { (Abeokuta Formation) }\end{array}$ & $\begin{array}{l}\text { GSN. BH. } \\
\text { No. }\end{array}$ & \begin{tabular}{|c|}
$\begin{array}{c}\text { Total Depth } \\
(\mathrm{m})\end{array}$ \\
\end{tabular} & \begin{tabular}{|c|}
$\begin{array}{c}\text { Depth to First Water } \\
(\mathbf{m})\end{array}$ \\
\end{tabular} & $\begin{array}{c}\text { Final Depth to Water } \\
(\mathrm{m})\end{array}$ & $\begin{array}{c}\text { Yield } \\
(\text { lits/hr) }\end{array}$ & \begin{tabular}{|c|}
$\begin{array}{c}\text { Draw Down } \\
(\mathrm{m})\end{array}$ \\
\end{tabular} & $\begin{array}{c}\text { Specific Capacity } \\
(\text { lits } / \mathbf{h r} / \mathbf{m})\end{array}$ & Remarks \\
\hline 1 & Aiyetoro 2 & 2438 & 63 & 31.2 & 31.2 & 2340 & 15 & & Pre Cambrian-45.9-63 m \\
\hline 2 & Aiyetoro 2 & 2439 & 53.7 & 20.7 & 20.7 & 18900 & 3.6 & 5250 & Pre Cambrian-45.9-63 m \\
\hline 3 & Ijebu Ife & 1808 & 57 & 42 & 39.9 & 10655 & 10.6 & 1035 & \\
\hline 4 & Ijebu Ode & 2620 & - & - & - & - & - & - & Abandoned Pre Cambrian-Very shallow \\
\hline 5 & Ijebu Ode & 2597 & 69.9 & 46.2 & 46.2 & 10800 & 11.4 & 945 & Pre Cambrian-54.6-69.6 m \\
\hline 6 & Ijebu Ode & 2598 & 54 & - & - & - & - & - & Abandoned Pre Cambrian-18.3-54 m \\
\hline 7 & Imushin & 1807 & 87 & 55.8 & 52.8 & 13500 & 3.3 & 4080 & Pre Cambrian-72.9-87 m \\
\hline 8 & Imushin & 2616 & 75.9 & - & 51.9 & 35100 & 1.8 & 19500 & Pre Cambrian-65.4-75 m \\
\hline 9 & Ishage & 2435 & 75 & 29.1 & 19.8 & 31050 & 9.6 & 3225 & Pre Cambrian-67.8-75 m \\
\hline 10 & Meko & 2436 & 57.9 & 42.3 & 42.3 & 1620 & 10.5 & - & Pre Cambrian-54.6-57.9 m \\
\hline \multicolumn{10}{|c|}{ (a) Borehole Locality (Fugar Area) } \\
\hline 11 & Agenebodo & 2604 & 127.2 & 105.9 & 105.9 & - & - & - & Not tested \\
\hline 12 & Fugar & 1136 & 69.3 & - & - & - & - & - & Abandoned \\
\hline 13 & Fugar & 1179 & 157.5 & - & 129.6 & 4500 & - & - & - \\
\hline 14 & Fugar & 2603 & 157.8 & 129.6 & 129.6 & - & - & - & Not tested \\
\hline 15 & Ogbona & 2613 & 213 & - & 183.3 & - & - & - & Not tested \\
\hline \multicolumn{10}{|c|}{ (b) Borehole Locality (Ewekoro Formation) } \\
\hline 16 & Ewekoro & 2614 & 90 & - & - & 58500 & - & - & $\begin{array}{c}\text { Artesian flow 90-135 lits/hr Obtained } \\
\text { near the bottom of the hole }\end{array}$ \\
\hline 17 & Iboro $^{2}$ & 2433 & 48 & 13.5 & 10.2 & 36000 & 3 & 1200 & - \\
\hline 18 & Labour & 2434 & 33.6 & - & - & 32850 & 3 & 10950 & - \\
\hline 19 & Ifon $^{2}$ & 2602 & 79.5 & 64.5 & 61.8 & 12600 & 2.1 & 6000 & - \\
\hline 20 & Igbogila $^{2}$ & 2612 & 70.5 & 11.4 & 10.2 & 28350 & 11.7 & 2415 & - \\
\hline 21 & Itori & 1583 & 96 & - & - & - & - & - & $\begin{array}{l}\text { Artesian flow at } 81 \mathrm{~m}, 450 \text { lits } / \mathrm{hr} \text {; at } \\
92.7 \mathrm{~m} 45000 \text { lits }\end{array}$ \\
\hline 22 & Yemoji & 1590 & 348 & - & - & - & - & - & - \\
\hline \multicolumn{10}{|c|}{ (c) Borehole Locality (Ibeshe Area) } \\
\hline 23 & \begin{tabular}{|c|} 
Ibeshe $^{2}$ \\
\end{tabular} & 2437 & 121.2 & 57.5 & 57.9 & 10.26 & 9.3 & 1095 & - \\
\hline 24 & Ilaro & 2611 & 132.9 & 17.4 & 20.4 & 26.55 & 22.5 & 1170 & - \\
\hline \multicolumn{10}{|c|}{ (d) Borehole Locality (Imo Shale) } \\
\hline 25 & Sabon Gida & 2601 & 121.2 & 41.4 & - & 13.05 & 51 & 255 & Artesian flow 900 to 1350 lits $/ \mathrm{hr}$ \\
\hline
\end{tabular}

After Offodile [32]. 
Table 3: Borehole information from Osse Owena Basin.

\begin{tabular}{|c|c|c|c|c|c|c|c|c|c|}
\hline \multicolumn{2}{|c|}{$\begin{array}{l}\text { Borehole Locality } \\
\text { (Ameki Formation) }\end{array}$} & \multirow{2}{*}{$\begin{array}{c}\text { GSN. BH. No. } \\
- \\
\end{array}$} & \multirow{2}{*}{$\begin{array}{c}\text { Total Depth } \\
(\mathbf{m})\end{array}$} & \multirow{2}{*}{$\begin{array}{c}\begin{array}{c}\text { Depth to First Water } \\
(\mathbf{m})\end{array} \\
27.6 \\
\end{array}$} & \multirow{2}{*}{$\begin{array}{c}\begin{array}{c}\text { Final Depth to Water } \\
(\mathbf{m})\end{array} \\
23.1 \\
\end{array}$} & \multirow{2}{*}{$\begin{array}{c}\begin{array}{c}\text { Yield } \\
\text { (lits/hr) }\end{array} \\
8325 \\
\end{array}$} & \multirow{2}{*}{$\begin{array}{c}\text { Draw Down } \\
(\mathbf{m})\end{array}$} & \multirow{2}{*}{$\begin{array}{c}\text { Specific Capacity } \\
(\text { lits } / \mathbf{h r} / \mathbf{m})\end{array}$} & \multirow{2}{*}{$\begin{array}{c}\text { Remarks } \\
- \\
\end{array}$} \\
\hline 1 & Asaba & & & & & & & & \\
\hline 2 & Asaba & - & 72 & 22.5 & 25.5 & 9450 & 3 & 31 & - \\
\hline 3 & Asaba & - & 67.5 & 16.5 & 17.4 & 18000 & - & - & - \\
\hline 4 & Asaba & - & 45.6 & 25.2 & 22.2 & 95850 & 3 & 31950 & - \\
\hline 5 & Asaba2 & - & $\begin{array}{ll}44.7 \\
\end{array}$ & 26.4 & 24 & 95850 & 4.2 & 22815 & - \\
\hline 6 & Isse-Uku & - & 112.5 & 102.5 & - & - & - & - & Abandoned \\
\hline 7 & Isse-Uku & - & 120 & - & - & - & - & - & Abandoned \\
\hline 8 & Iuue & - & 241.5 & - & - & - & - & - & Abandoned \\
\hline 9 & $\begin{array}{l}\text { O g w a s h i - } \\
\text { Uku }\end{array}$ & - & 89.7 & - & - & - & - & - & Abandoned \\
\hline 10 & Uburu & - & 114 & - & 108.5 & - & - & - & Abandoned \\
\hline
\end{tabular}

Borehole Locality (Benin Formation)

\begin{tabular}{|c|c|c|c|c|c|c|c|c|c|}
\hline \multicolumn{10}{|c|}{ Borehole Locality (Benin Formation) } \\
\hline 11 & Abafon & - & 45.6 & - & 41.4 & - & - & 16.67 & - \\
\hline 12 & Ado Odo & - & 96 & - & I1 & 45000 & 2.7 & 9990 & - \\
\hline 13 & Ado Odo & - & & & - & - & - & & \\
\hline 14 & Agbon & - & 63 & - & 45 & 40500 & - & - & - \\
\hline 15 & Agbon & - & 75 & - & 7.5 & 45000 & 4.5 & - & - \\
\hline 16 & Agbon & - & 75 & - & 7.5 & 45000 & - & 32.13 & - \\
\hline 17 & Benin City & - & 110.4 & - & 56.4 & 29.25 & - & 27.55 & - \\
\hline
\end{tabular}

Borehole Locality (Ameki Formation)

\begin{tabular}{|c|c|c|c|c|c|c|c|c|c|}
\hline 18 & Benin City & - & 61.8 & - & 15 & 67500 & 2.1 & - & - \\
\hline 19 & Ethiope & - & 34.5 & - & 10.5 & 49500 & 1.8 & - & - \\
\hline 20 & Sapele & - & 37.5 & - & 4.8 & 31500 & - & - & - \\
\hline 21 & Sapele & - & 37.5 & - & - & - & - & - & No Data \\
\hline 22 & Sapele & - & 37.5 & - & 5.1 & 27000 & - & - & - \\
\hline 23 & Sapele & - & - & - & - & - & - & - & No Data \\
\hline
\end{tabular}

After Offodile [32].

gap to latitude $7^{\circ} 53^{\prime}$ before winding its way westwards through Oshogbo and Ede and Southwards to enter Lagos lagoon about $8 \mathrm{~km}$ east of Epe [63,67]. A considerable part of the basin is underlain by rocks of the Precambrian Basement Complex, most of which are very ancient. This Basement Complex rocks showed significant variations in grain size and mineral composition [63]. The rocks are quartz gneisses and schist consisting essential of quartz with small amounts of white micaceous minerals. Even though the outcrops are visible, large areas are overlain by layers of laterite soil formed by weathering and decomposing the parent rock material. The minerals' origin has been dealt with based on heavy mineral studies along the river basin. Moreover, the sedimentary rocks of Cretaceous and Tertiary deposits are found in the southern sector of the basin [63]. Generally, in coastal basins of southwestern Nigeria, groundwater is contained in four principal aquifers [56]:

- The first is the shallow aquifer, which contained the Recent Sediments along the Atlantic Sea coast and river valleys. It is used for minimal private domestic supplies through dug wells and shallow boreholes.

- The second and third aquifers are in the Coastal Plains Sands Formation. They are exploited through hand-dug shallow wells in some areas, shallow - and profound - boreholes. These aquifers provide considerable amounts of water for water supplies. This is the principal aquifer exploited, particularly in Lagos and its environs.
- The fourth aquifer is the deep and highly productive Abeokuta formation, which was discussed in previous sections.

A few boreholes located mostly in Ikeja industrial area in Lagos only extract water from the fourth aquifer. The water from this aquifer is hot with temperatures as high as $80^{\circ} \mathrm{C}$ recorded in a few boreholes. This aquifer is undergoing massive development in adjoining Ogun State when encountered at shallower depths of between 300 and 550 meters. Figure 12 is a north-south geologic cross-section showing various Formations in the sedimentary basin. In Figure 12, a hydrogeologic cross-section from west to east along the coast shows both the lithologic and water-quality variations in the Coastal Plains Sands and Recent Sediments [56].

The delineation of shallow aquifers in the coastal plain sands of Okitipupa Area, Southwestern Nigeria, revealed two central aquifer units within the Okitipupa Area, Southwestern Nigeria [56]:

- The upper/surficial aquifer system, which occurs at depths ranging from $5.8 \mathrm{~m}$ (around Agbabu) to $61.5 \mathrm{~m}$ (around Ikoya), and with materials of higher average resistivity (504.7 $\Omega \mathrm{m}$ ), suggestive of gravelly/coarse to medium-grained sand; and

- The intermediate aquifer system, characterized by depth range of 32.1-127.5 m, average resistivity of $296.8 \Omega \mathrm{m}$, typical of medium-grained sand saturated with water. 


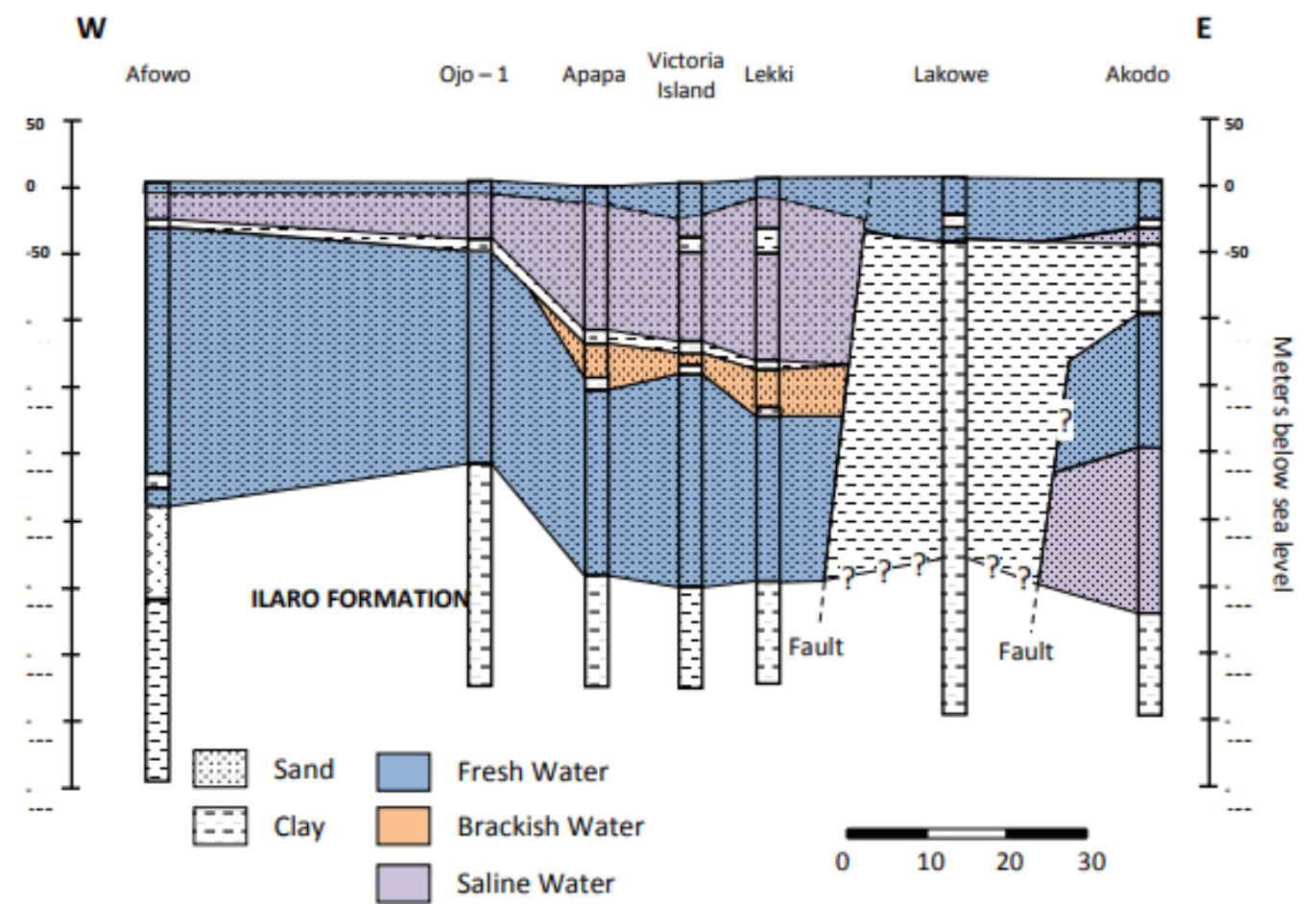

Figure 12: Hydrogeological cross-section of coastal basins along with Lagos State. After Oteri and Ayeni [56].

The highly resistive, impermeable materials overlying the aquifer units around Ajagba, Aiyesan, Agbetu, Ilutitun, Igbotako, and Erinj suggests that the aquifer units are less vulnerable to near-surface contaminants than in Agbabu, Igbisin, Ugbo, and Aboto where less resistive materials overlie aquifers. However, this indicates that the aquifer cannot be recharged in these areas. The geoelectric sequence suggests subsurface geology characterized by the alternation of sands/ gravel, clay/shale, and sandstone occurring at varying depths with variable thicknesses. The sand and gravel layers constitute the aquifer units [56]. The aquifer units' geoelectric parameters were determined by interpreting the sounding curves, assisted by the distinctive resistivity contrasts between the discrete geoelectric layers.

The upper and lower aquifer horizons work are referred to as the surficial (upper) and intermediate (lower) aquifers. In a different study by Adepelumi, Ako [68], which delineates saltwater intrusion into the freshwater aquifer of Lekki Peninsula, Lagos, Nigeria, the study delineates four distinct resistivity zones viz:

- The unconsolidated dry sand having resistivity values ranging between 125 and $1,028 \mathrm{Xm}$ represents the first layer;

- The fresh water-saturated soil having resistivity values which correspond to $32-256 \mathrm{Xm}$ is the second layer;

- The third layer is interpreted as the mixing (transition) zone of fresh with brackish groundwater. The resistivity of this layer ranges from 4 to $32 \mathrm{Xm}$; and

- Layer four is characterized by resistivities values generally below $4 \mathrm{Xm}$ reflecting an aquifer possibly containing brine. The rock matrix, salinity, and water saturation are the major factors controlling the Formation's resistivity. Furthermore, this study illustrates that saline water intrusion into the aquifers can be accurately mapped using the surface DC resistivity method.

\section{The Crystalline Basement Terrain}

The Basement Complex terrains of South-western Nigeria are underlain by Precambrian basement rocks, which comprise crystalline igneous and metamorphic rocks mostly granite/porphyritic granite, granite-gneiss, quartz-schist, migmatite as well as Augen-gneiss, Pegmatite intrusions and variably Migmatized Biotite-hornblende Gneiss [28,69,70]. Descriptions on the field and petrographic/ mineralogical characteristics of the different rock types are subject to various works. Textural and compositional attributes are wide-ranging. Directional fabrics such as foliation, lineation, and lamination are often developed in the Gneisses, Schists, Quartzites, and Tectonized rocks [71]. From the hydrogeologic perspective, unweathered basement rock contains negligible groundwater; however, the significant aquiferous unit can develop within the weathered overburden and fractured bedrock. It is this weathered and fractured zone, which forms potential groundwater zones. However, several factors that usually contribute to the weathering and development of fracture systems in the basement rocks can be summarized as follows [71]: (i) Presence and stress components of fractures; as conduit zones, hydrogeomorphological conditions that dictate the influence of weathering agents; (ii) Hydro-climatic/temperature regimes that dictate chemical weathering pace; and (iii) Mineral contents of the rock which affect the degree of weathering/overburden thickness.

The availability of groundwater in Pre Cambrian-Basement of southwestern Nigeria depends not only on the geology but also on the complex interactions of the various hydroclimatic and geomorphologic 
factors [72,73]. Accordingly, several methods have been established to locate favourable sites for groundwater resources extraction within basement rocks. These include remote sensing geophysical methods and geomorphological studies [71]. Assessment of previous studies on groundwater in the crystalline basement terrain of southwestern Nigeria discovered that the hydrogeological setting of the terrain is characterized by weathered saprolite units with varied thickness over the different bedrock units, Porphyritic Granites, Granite-gneiss, Migmatite, Pegmatite, and Quartz-schist settings. Such a setting suggests the influence of rock types and mineralogy on the extent of fracturing and weathering. Consequently, groundwater occurrences in the study area are in localized, disconnected phreatic regolith aquifers, practically under unconfined to semi-confined conditions. Nonetheless, groundwater in the study area can be categorized under two central units: area with highly weathered and fractured bedrock units and poorly weathered/sparsely fractured bedrock units [71]. In an area with deeply weathered regolith and highly fractured zones, groundwater occurrences usually depend on the thickness of the water-bearing rock; this rock can be gravelly and fractured with possible quartz veins within the deep weathered zone of between 10 $\mathrm{m}$ to $30 \mathrm{~m}$. These are characteristic of areas underlain in the study area by weathered crystalline and metamorphic rocks such as schist/ quartz-schist, fractured granite-gneiss, and porphyritic granites as well as Augen gneiss with vertical fracture zones. These are generally characterized by moderate to high yield of about $75 \mathrm{~m}^{3} /$ day and up to $>150 \mathrm{~m}^{3} /$ day. The borehole depth usually varies from 20 to $60 \mathrm{~m}$, while the saturated thickness varies from 20 to $35 \mathrm{~m}$ below the ground surface [71]. In areas where the weathered zone is thin or absent, groundwater is usually tricky due to widely spaced fractures and the weathered zone's localized zone/pockets. In the study area, these are characteristic of areas underlain by crystalline and metamorphic rocks, especially migmatite and variably Migmatized gneiss characterized by thin/ shallow overburden unit of usually less than 10 meters in thickness and low yield of generally less than $75 \mathrm{~m}^{3} /$ day. In such a setting also, the borehole depth varies from 20 to $30 \mathrm{~m}$ while saturated thickness varies from 8 to $20 \mathrm{~m}$ below the ground surface [71]. Nonetheless, towards the base of the weathered zone at the interface with the fresh bedrock, the permeability is usually high, allowing water to move freely due to the low proportion of clayey materials. However, deep-seated fractures are vital in such situations and can sometimes provide appreciable water supplies, mainly when tectonically controlled. Wells or boreholes that penetrate this horizon can usually provide sufficient water to sustain even hand-dug wells. Due to the complex interactions of the various factors affecting weathering in a typical basement complex setting like the study area, the groundwater potential zone distribution can be erratic and may not be present in some locations [71]. The analysis that involved characterization of weathered overburden revealed estimated overburden thickness using geoelectrical VES surveys from 3.8 to 50 meters with a mean value of about 20 meters as dictated by bedrock types. These values are within the range of values obtained for similar Basement Complex terrains of Africa. Furthermore, it was observed that areas with thin/shallow overburden coincided mostly with areas underlain by variably Migmatized gneiss complex, while the area with thicker overburden unit coincided with area mainly underlain by schist. However, the quartzite/quartz-schist setting coincided with areas of moderate to shallow overburden thickness [71]. In a nutshell, the varied thickness and the weathered overburden units' isolated pockets also confirm the localized nature of weathered basement aquifers under the crystalline basement setting. The implication of this lies in the fact that there is the need for careful characterization and delineation of areas of possible fracturing and deep weathering as an aquiferous zone in respect of groundwater developments in Basement Complex settings of the study area. Therefore, the present study addresses the aspect of characterization of the groundwater potential using integrated GIS, RS, and MCDA techniques in conjunction with conventional hydrological and hydrogeological data [71]. Although the hydrogeology of southwestern Nigeria's coastal basins is well described in the literature, a comprehensive description of its hydrochemistry has been lacking. The following section presents a synthesis of physicochemical physiognomies of groundwater in the basin.

\section{Groundwater Chemistry}

\section{Physical Chemistry}

Figures 13-15 present a summary of groundwater's physical and chemical parameters in southwestern Nigeria's coastal basins. Evaluation of $\mathrm{pH}$ concentration from 210 locations showed that $\mathrm{pH}$ ranged from 3.9 to 10.2 with a mean $\mathrm{pH}$ value of 7.4. Generally drinking water having $\mathrm{pH}<7$ is measured as acidic, and $\mathrm{pH}>7$ is considered basic. The normal range for $\mathrm{pH}$ in surface water systems is 6.5 to 8.5 and for groundwater aquifers 6 to 8.5 [74-76]. Unlike the Niger Delta Basin, groundwater in coastal basins of southwestern Nigeria is slightly alkaline. Alkalinity is a degree of the water's capacity to resists a change in $\mathrm{pH}$ that would tend to make the water more acidic. The measurement of alkalinity and $\mathrm{pH}$ is needed to determine the water's corrosivity [77-80]. The $\mathrm{pH}$ of clean water is 7 at $25^{\circ} \mathrm{C}$, but when exposed to the atmosphere's carbon dioxide, this equilibrium results in a $\mathrm{pH}$ of approximately 5.2. Because of the association of $\mathrm{pH}$ with atmospheric gasses and temperature, it is strongly recommended that the water is tested as soon as possible. The water's $\mathrm{pH}$ is not a measure of the acidic or basic solution's strength and alone does not provide a full picture of the characteristics or limitations with the water supply. In general, groundwater sources with low $\mathrm{pH}(<6.5)$ could be acidic, soft, and corrosive. Therefore, the water could leach metal ions such as iron, manganese, copper, lead, zinc from the aquifer, plumbing fixtures, and piping. Consequently, groundwater with low $\mathrm{pH}$ could contain elevated levels of toxic metals, cause premature damage to metal piping, and have associated aesthetic problems such as a metallic or sour taste, laundry staining, and the characteristic bluegreen staining of sinks and drains [81-83].

Groundwater sources having $\mathrm{pH}>8.5$ could indicate that the water is hard [84-86]. Hard water does not pose a health risk but can cause aesthetic problems. These problems include:

- Formation of a 'scale' or precipitate on piping and fixtures causing water pressures and the interior diameter of piping to decrease;

- Causes an alkali taste to the water and can make coffee taste bitter; 

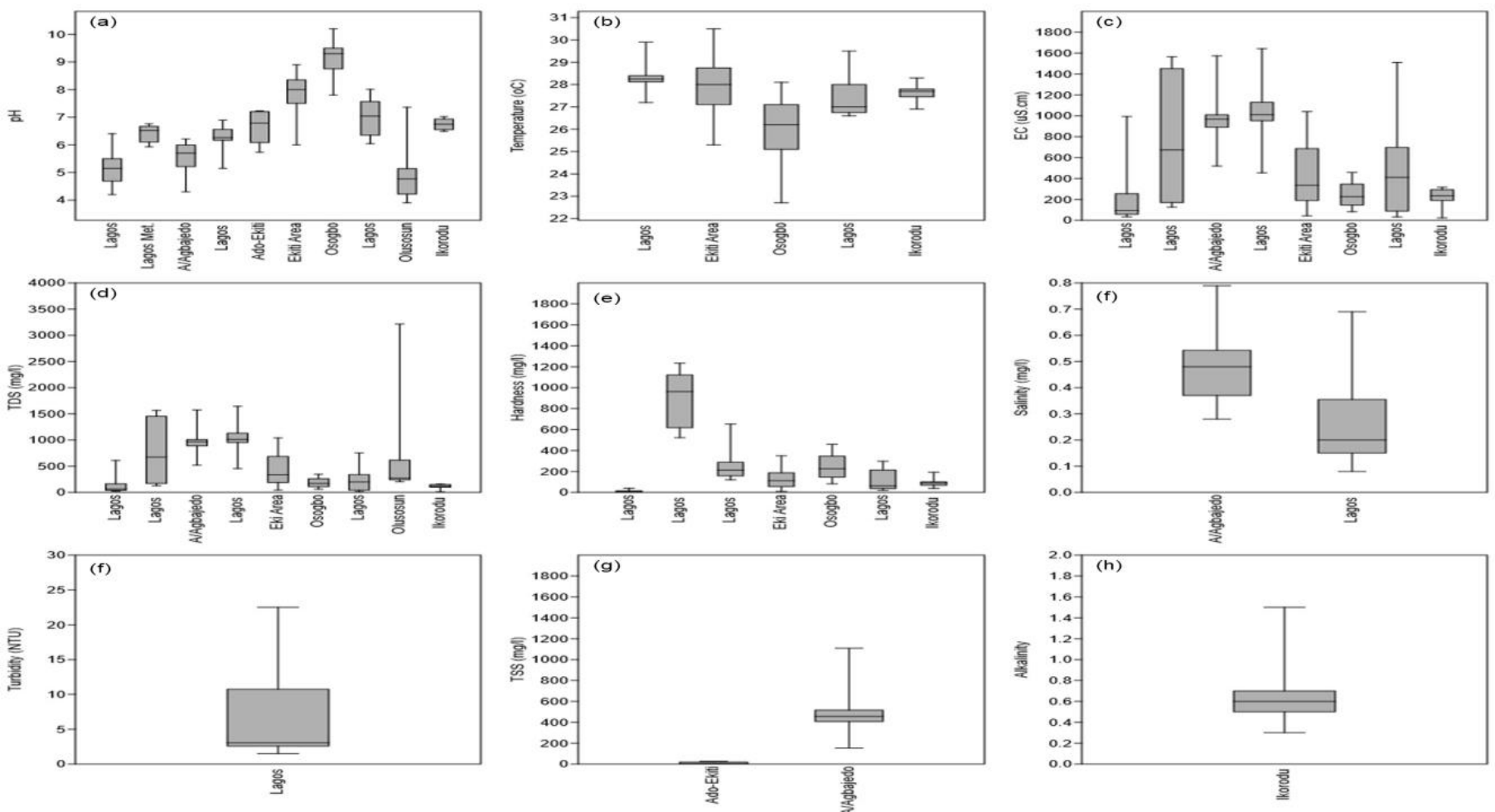

Figure 13: Hydrogeological cross-section of coastal basins along with Lagos State.

(a)

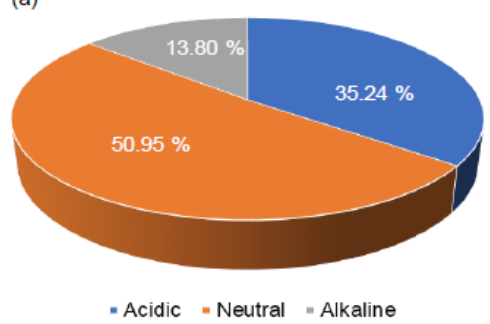

(c)

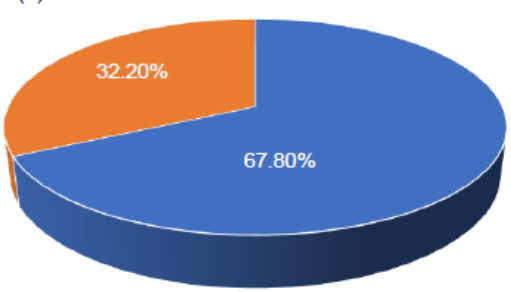

- Good for drinking = Permissible = Doubtful

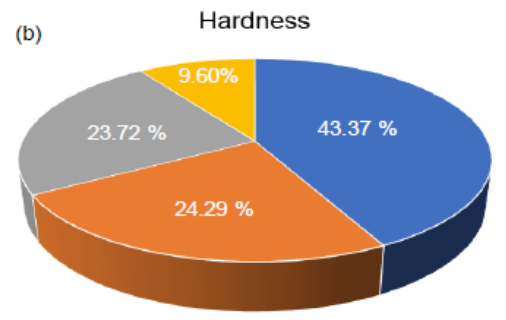

- Soft $=$ Moderate Hard " Hard " Very Hard

(d)

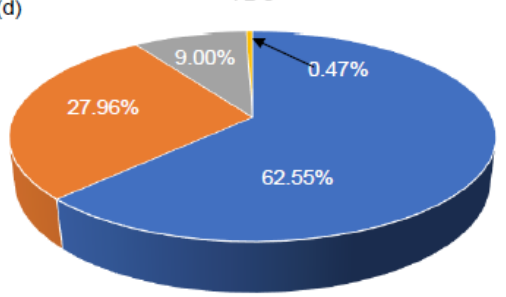

Required for drinking

- Unsuitable for drinking and irrigation

Figure 14: Groundwater classification (a) pH, (b) Total hardness, (c) Conductivity and (d) TDS.

- Formation of a scale or deposit on dishes, utensils, and laundry basins;

- Difficulty in getting soaps and detergents to foam and Formation of insoluble precipitates on clothing, etc.; and Decreases efficiency of electric water heaters.

The temperature ranged from 22.7 to $30.5^{\circ} \mathrm{C}$, with a mean value of $27.5^{\circ} \mathrm{C}$. The causes for the temperature rise in aquifers are numerous, and these are directly linked to the continuing structural developments and the existing uses at the earth's surface. These influences can be direct or indirect. The direct influences on the groundwater temperature include all heat inputs to the groundwater through the sewage network, district-heat pipes, power lines, and sources connected with groundwater heat use and storage [87-89]. The indirect influences on groundwater temperature processes are linked with urbanization-related changes in the heat balance in the near-surface atmosphere. The most important factors are: 

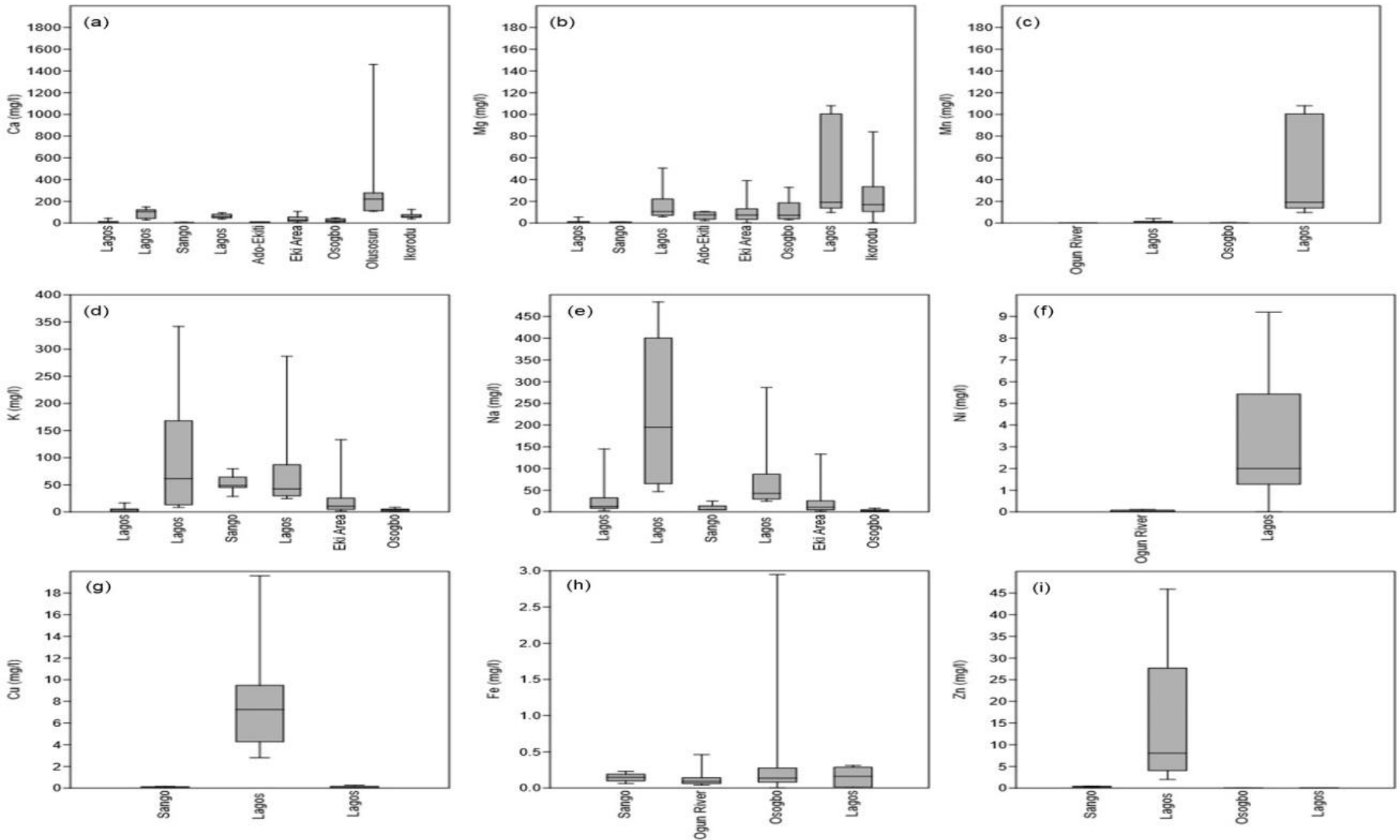

Figure 15: Cation chemistry (a) Ca, (b) $\mathrm{Mg}$, (c) $\mathrm{Mn}$, (d) K, (e) Na. (f) Ni, (g) Cu, (h) Fe, and (i) $\mathrm{Zn}$.

- The disturbance of the water balance due to a high degree of surface imperviousness;

- The change of soil characteristics caused by an aggregation of structures (differences in the near-surface heat input and heat capacity);

- Changes in the irradiance balance by changes in the atmospheric composition; and

- Anthropogenic heat generation (domestic heating, industry, and transport).

The differences mentioned above cause changes in the heat balance by comparison with the areas surrounding the city. The city heats itself slowly, stores more heat overall, and passes it on again slowly to the surrounding areas, i.e., it can generally be considered an enormous heat storage unit $[90,91]$. Over the long term, this process increases the annual mean air and soil temperatures. The long-term warming of the near-surface soil also leads to a heating of the groundwater. Since the temperature affects the physical qualities and the groundwater's chemical and biological nature, deterioration of groundwater quality and an impairment of the groundwater fauna may result from high temperatures [92-94]. The concentration of EC was synthesized from 177 locations from the basins. Conductivity values ranged from 31.9 to $1643 \mu \mathrm{S} / \mathrm{cm}$ with a mean value of $526.47 \mu \mathrm{S} / \mathrm{cm}$. Electrical conductivity is widely used for monitoring the mixing of fresh and saline water, for separating stream hydrographs, and for geophysical mapping of contaminated groundwater $[95,96]$. Distilled water should typically have an $\mathrm{EC}$ of less than $0.3 \mu \mathrm{S} / \mathrm{cm}$. For groundwater, $\mathrm{EC}$ values greater than $500 \mu \mathrm{S} \mathrm{cm}-1$ indicate that the water may be polluted, although values as high as $2000 \mu \mathrm{S} / \mathrm{cm}$ may be acceptable for irrigation water [97,98]. In Europe, the EC of drinking water should be no more than $2500 \mu \mathrm{S} / \mathrm{cm}$; water with a higher TDS may have water quality problems and be unpleasant to drink [99-101]. Synthesis of hardness from 211 locations revealed that hardness ranged from 11 to $3215 \mathrm{mg} / \mathrm{l}$ with a mean value of $467.05 \mathrm{mg} / \mathrm{l}$. Initially, water hardness was understood to be the capacity of water to precipitate soap. Hard water does not allow soap to form as many suds. Water high in hardness is detrimental to plumbing and will reduce the life of water heaters. Water softeners will typically reduce hardness to below $10 \mathrm{mg} / \mathrm{l}$. However, they replace the calcium and magnesium metals with sodium which is undesirable for low salt intake diets [102-104]. Water softener companies often discuss hardness in 'Grains per Gallon' instead of the standard units $\mathrm{mg} / \mathrm{l}$. To convert hardness from $\mathrm{mg} / \mathrm{L}$ to grains per gallon, multiply $\mathrm{mg} / \mathrm{l}$ by 17 . Thus, $525 \mathrm{mg} / \mathrm{l}$ is equal to $31 \mathrm{gram} /$ gallon. Salinity ranged from 0.08 to $1109 \mathrm{mg} / \mathrm{l}$ with a mean value of $178.90 \mathrm{mg} / \mathrm{l}$. There is a substantial reporting on salinity in coastal basins of southwestern Nigeria. All-natural water holds some salt level, and in groundwater, the concentration can naturally vary from fresh to saltier-thanseawater. While small amounts of salt are vital for life, high levels can limit groundwater use and affect ecosystems that depend on groundwater. Small quantities of salt are deposited on the landscape every time it rains. Evaporation and plant transpiration remove water from the landscape but leave the salt behind. It concentrates salt over time. Evaporation can also directly increase groundwater salinity in 
areas where groundwater is close to the surface. Old groundwater can also become saltier as it passes through aquifers and picks up salts from dissolved minerals.

Although salt in the southwestern Nigeria landscape's coastal aquifers is natural, groundwater and salt movement's salinity into groundwater-dependent ecosystems can be increased by human activities. Increases in groundwater salinity can be caused by:

- Increased groundwater recharge because of irrigation, which mobilizes salts naturally accumulated in the soil (irrigation salinity);

- Increased groundwater recharge because of land clearing, bringing groundwater near the land surface, causing evaporation from the soil surface and salt accumulation (dryland salinity);

- Leaking pipes, over-watering of gardens, and runoff from compacted surfaces can raise groundwater levels and concentrate salts in urban areas, which can lead to salt damage on buildings and roads (urban salinity);

- Over-pumping near the coast, which can cause seawater to seep into replenishing water levels.

Groundwater salinity can also be reduced at times, such as when rapid recharge from flooding flushes out or dilutes salty groundwater. Broadscale changes in groundwater salinity occur very slowly, over decades or longer. Therefore, groundwater salinity is usually monitored rarely except where human impacts are of concern. Measurements on Turbidity, TSS, and Alkalinity were not much in the coastal basins of southwestern Nigeria. Turbidity ranged from 0.86 to $26.34 \mathrm{mg} / \mathrm{l}$, with a mean value of $8.06 \mathrm{mg} / \mathrm{l}$. This estimate was based on two studies (Figure 13f). Therefore, more reporting on turbidity is required in the basin. There is currently little information regarding turbidity in groundwater, and the cause is not fully understood. The common assumption is that groundwater turbidity indicates a fast transport pathway connecting potentially contaminated surface water with the aquifer. Studies found no relationship between turbidity and microbiology, although Chalk sources appear more susceptible to E. coli than other aquifers [105]. The occurrence of turbidity tends to be site-specific with a variety of causes. Mitigation measures in groundwater might include variable speed pumps, automatic pumping to waste, blending, or engineered solutions. Discussion on TSS was based on one study (Figure 13g). Total suspended solids ranged from 153 to $1109 \mathrm{mg} / \mathrm{l}$ with a mean value of $472.67 \mathrm{mg} / \mathrm{l}$. Total Suspended Solids (TSS), also known as non-filterable residue, are those solids (minerals and organic material) that remain trapped on a $1.2 \mu \mathrm{m}$ filter. Suspended solids can enter groundwater through runoff from industrial, urban, or agricultural areas [106]. Elevated TSS can reduce water clarity, degrade habitats, clog fish gills, decrease photosynthetic activity, and cause an increase in water temperature. TSS has no drinking water standard; drinking water with high TSS concentration can increase people's severity with liver diseases. Similarly, there is not much reporting on alkalinity from these basins. Alkalinity ranged from 0.3 to $1.5 \mathrm{mg} / \mathrm{l}$, with a mean concentration of $0.67 \mathrm{mg} / \mathrm{l}$ (Figure 13h). Alkalinity is not a chemical in water, but, instead, it is a property of water-dependent on the presence of certain chemicals in the water, such as bicarbonates, carbonates, and hydroxides. Groundwater aquifers with high alkalinity will experience less of a change in its acidity, such as acidic water, such as acid rain or an acid spill, introduced into the water body [107-109]. In a surface water body, such as a lake, the water's alkalinity comes mostly from the lake's rocks and land. Precipitation falls in the lake's watershed, and most of the water entering the lake comes from runoff over the landscape. If the landscape is in an area containing rocks such as limestone, then the runoff picks up chemicals such as calcium carbonate $(\mathrm{CaCO} 3)$, which raises the water's $\mathrm{pH}$ and alkalinity. In areas where the geology contains large amounts of granite, lakes will have lower alkalinity. A pond in a suburban area, even in a graniteheavy area, as in some parts on the coastal basins (e.g., Lagos and its environs), could have high alkalinity due to runoff from home lawns where limestone has been applied. However, studies are required for further evaluation. Studies on dissolved oxygen from coastal basins of southwestern Nigeria are quite small in number. Ayolabi, Folorunso [110]'s integrated geophysical and geochemical methods for environmental assessment of the municipal dumpsite system in Lagos revealed DO ranging between 4 to $4.4 \mathrm{mg} / \mathrm{l}$ with a mean value of $4.1 \mathrm{mg} / \mathrm{l}$. Similarly, Awomeso, Taiwo [111]'s study on the pollution of a waterbody by textile industry effluents in Lagos, Nigeria showed that COD concentration varies with distance from the discharge point. The concentration of was $890 \mathrm{mg} / \mathrm{l}$ at 0 meters, $600 \mathrm{mg} / \mathrm{l}$ at 50 meters, 214 $\mathrm{mg} / \mathrm{l}$ at 100 meters, 1703 at 150 meters, 1172 ta 200 meters, $10 \mathrm{mg} / \mathrm{l}$ at 250 meters, $1693 \mathrm{mg} / \mathrm{l}$ at 300 meters, $860 \mathrm{mg} / \mathrm{l}$ at 350 meters, 1901 $\mathrm{mg} / \mathrm{l}$ at 400 meters and $10 \mathrm{mg} / \mathrm{l}$ at 450 meters respectively. Omale and Longe [112]'s, assessment of the impact of abattoir effluents on River Illo, Ota, Nigeria showed that BOD ranged from 140 to $670 \mathrm{mg} / \mathrm{l}$ with a mean value of $333.33 \mathrm{mg} / \mathrm{l}$. Most of the studies reporting BOD came from surface water bodies. Groundwater is yet to be fully explored in southwestern Nigeria's coastal basins, based on these parameters. Dissolved oxygen significantly affects groundwater quality by regulating the valence state of trace metals and constraining dissolved organic species' bacterial metabolism [113-115]. Consequently, the measurement of dissolved oxygen concentration should be considered vital in most water quality researches. Measurements of dissolved oxygen have been often ignored in groundwater monitoring. Oxygen has regularly been assumed absent below the water table; $\mathrm{O} 2$ measurements are not mandated by drinking water standards. Regular organic debris and organic waste derived from wastewater treatment plants, failing septic systems, and agricultural and urban runoff act as food sources for water-borne bacteria. Bacteria decompose these organic constituents using DO, consequently reducing the DO present for aquatic organisms. Chemical oxygen demand does not discriminate between biologically available and inert organic matter, and it is a measure of the total quantity of oxygen required to oxidize all organic material into carbon dioxide and water [116-119]. The COD values are always greater than $\mathrm{BOD}$ values, but $\mathrm{COD}$ measurements can be made in a few hours while BOD measurements take five days. Since parameters play a significant role in groundwater quality, it is recommended that such parameters are measured throughout the coastal basin of southwestern Nigeria. Figure 14 presents the groundwater classification based on $\mathrm{pH}$, Hardness, Conductivity, and TDS. Based on $\mathrm{pH} 50.95 \%$ of groundwater sources in coastal basins 
of southwestern Nigeria fall in neutral class, $35.24 \%$ fall in acidic class, and $13.80 \%$ fall in alkaline class. Conversely, total hardness is also varying in the basin. About $43.37 \%$ of groundwater sources fall in soft class, $24.29 \%$ fall in intermediate class, $23.72 \%$ fall in hard class, and $9.60 \%$ fall in the very hard-water class. About $67.80 \%$ of groundwater sources have conductivity below $750 \mu \mathrm{S} / \mathrm{cm}$, and $32.24 \%$ have EC values between 750 to $2250 \mu \mathrm{S} / \mathrm{cm}$. Low TDS levels further show the low conductivity of groundwater sources in the basin. About $62.55 \%$ groundwater sources have TDS below $500 \mathrm{mg} / \mathrm{l}, 27.96 \%$ have TDS concentration between 500 to $1000 \mathrm{mg} / \mathrm{l}, 9.00 \%$ have TDS level between 1000 to $3000 \mathrm{mg} / \mathrm{l}$ and $0.47 \%$ have TDS above $3000 \mathrm{mg} / \mathrm{l}$. This variability is further illustrated in Figure 14d.

\section{Cation Chemistry}

Understanding the chemical physiognomies of groundwater is essential as a result of their contrasting sources. As soon as their concentration is above the suggested reference guidelines, these prerequisites may render groundwater unusable. Chemical essentials including $\mathrm{Ca}, \mathrm{Mg}, \mathrm{Cu}, \mathrm{Cd}, \mathrm{B}, \mathrm{Al}, \mathrm{K}, \mathrm{PO} 4, \mathrm{SO} 4 \mathrm{As}$, and $\mathrm{Cl}$, for instance, are primarily derived from rocks. Nonetheless, elements like NO3 and $\mathrm{SO} 4$ are derived mainly from anthropogenic sources $[118,119]$. Understanding the derivation and absorption level of these chemical elements in groundwater is needed for effective groundwater management. Generally, there is little reporting on $\mathrm{Al}, \mathrm{NH} 4$, and southwestern Nigeria's coastal basins. For instance, Ayolabi, Folorunso [110]'s analysis of the municipal dumpsite system in Lagos showed Al ranged from 0.001 to $1.641 \mathrm{mg} / \mathrm{l}$ with a mean value of $0.29 \mathrm{mg} / \mathrm{l}$.

Longe and Enekwechi [120] investigated potential groundwater impacts, and the influence of local hydrogeology on natural attenuation of leachate at a municipal landfill from Olusosun landfill showed that $\mathrm{NH} 4$ ranged from 0.14 to $1.5 \mathrm{mg} / \mathrm{l}$ with an average value of $0.41 \mathrm{mg} / \mathrm{l}$. A review of the level of arsenic in potable water sources in Nigeria and their potential health impacts by Izah and Srivastav [121]'s analysis showed that arsenic concentration in western Nigeria ranged from 0.00 to $0.38 \mathrm{mg} / \mathrm{l}$ at Ibadan, 0.00 to $0.05 \mathrm{mg} / \mathrm{l}$ in Odeda region, 0.03 to $0.47 \mathrm{mg} / \mathrm{l}$ at Ijebu land and 0.01 to $0.70 \mathrm{mg} / \mathrm{l}$ at Igun-ijesha. People are exposed to elevated levels of inorganic arsenic through drinking contaminated water, using contaminated water in food preparation and irrigation of food crops, industrial processes, eating contaminated food and smoking tobacco. Long-term exposure to inorganic arsenic, mainly through drinking water and food, can lead to chronic arsenic poisoning. Skin lesions and skin cancer are the most characteristic effects. The SON has recommended $0.2 \mathrm{mg} / \mathrm{l}$ as a maximum permissible limit in drinking water. Aluminium is an excellent metal in the earth's crust and is regularly found in the form of silicates such as feldspar. The oxide of $\mathrm{Al}$ known as bauxite provides a suitable source of uncontaminated ore. Aluminium can be selectively leached from rock and soil to enter groundwater aquifer. Aluminium is known to exist in groundwater in concentrations ranging from $0.1 \mathrm{ppm}$ to 8.0 ppm. $\mathrm{Al}$ can be present as Aluminum Hydroxide, a residual from the municipal feeding of aluminium (Aluminum Sulfate), or as Sodium Aluminate from clarification or precipitation softening. It has been known to cause deposits in cooling systems and contributes to the boiler scale. Aluminium may precipitate at normal drinking water $\mathrm{pH}$ levels and accumulate as a white gelatinous deposit. Aluminium is controlled in drinking water with a recommended Secondary Maximum Contaminant Level (SMCL). SMCL's are used when the taste, odour, or appearance of water may be adversely affected. In this case, the WHO [122] established that an Al concentration above 0.1$0.2 \mathrm{mg} / \mathrm{l}$ might impact colour but recognize that level may not be appropriate for all water supplies. The Nigerian Standard for Drinking Water Quality (NSDWQ) has recommended $0.2 \mathrm{mg} / \mathrm{l}$ as a maximum permissible limit because of potential neuro-degenerative disorders associated with high $\mathrm{Al}$ concentrations in water. The natural levels of $\mathrm{NH} 4$ in groundwater and surface water are usually below $0.2 \mathrm{mg} /$ litre. Anaerobic groundwaters may contain up to $3 \mathrm{mg} / \mathrm{l}$. Leached effluents from the concentrated rearing of farm animals can give rise to much higher levels in groundwater. Ammonia pollution can also rise from cement mortar pipe linings. Ammonia is an indicator of possible bacterial, sewage, and animal waste effluence. Contact from environmental sources is insignificant in comparison with the endogenous synthesis of NH4. Toxicological effects are observed only at exposures above about $200 \mathrm{mg} / \mathrm{kg}$ of body weight. Ammonia in drinking water is not of immediate health significance, and consequently, no health-based guideline value is proposed by SON. There are few studies on Barium concentration in groundwater from coastal basins of southwestern Nigeria. Odukoya and Abimbola [123]'s assessment of contamination of surface and groundwater within and around two dumpsites in Lagos revealed that $\mathrm{Ba}$ concentrations ranged from 40 to $100 \mathrm{mg} / \mathrm{l}$ with a mean value of $49 \mathrm{mg} / \mathrm{l}$ within and around abandoned dumpsite. Barium also ranged from $<0.001$ to 80 $\mathrm{mg} / \mathrm{l}$ with a mean value of $56 \mathrm{mg} / \mathrm{l}$ within and around active dumpsite. Barium is available as a trace element in both igneous and sedimentary rocks. Even though it is not found free, it occurs in several compounds, most commonly barium sulfate (or barite) and, to a lesser extent, barium carbonate (or witherite). Barium goes into the environment naturally via the weathering of rocks and minerals. Anthropogenic releases are primarily connected with industrial processes. The overall population is exposed to $\mathrm{Ba}$ through the ingestion of drinking water and foods, usually at low levels. Figure 15a presents a synthesis of Ca from groundwater from coastal basins of southwestern Nigeria. Calcium ranged from 1.49 to $1460 \mathrm{mg} / \mathrm{l}$ with a mean value of 56.78 $\mathrm{mg} / \mathrm{l}$. Calcium in drinking water is beneficial, but it is important to note that calcium is a significant constituent of hardness. Based on SON guidelines, $\mathrm{Ca}$ is not limited to drinking water. Based on the results of the WHO meeting of experts held in Rome, Italy, in 2003 to discuss nutrients in drinking water [124], the assembly focused its attention on $\mathrm{Ca}$ and $\mathrm{Mg}$, for which, next to $\mathrm{F}$, a sign of health benefits accompanied by their existence in drinking water is robust. The Ca's insufficient consumption has been accompanied by increased risks of osteoporosis, nephrolithiasis (kidney stones), colorectal cancer, hypertension and stroke, coronary artery disease, insulin resistance, and obesity. Most of these disorders have treatments but no cures. Due to a lack of convincing evidence for Ca's role as a single influential element about these diseases, estimates of the Ca requirement have been made based on bone health outcomes to improve bone mineral density. Calcium is exclusive among nutrients because the body's reserve is also functional: increasing bone mass is correlated to a decrease in fracture risk. There relatively high Ca level in these basins 
could be beneficial to the health of the people living there. Figure 15b presents a synthesis of $\mathrm{Mg}$ from groundwater in coastal basins of southwestern Nigeria. Evaluation of $\mathrm{Mg}$ from 183 sites across these basins showed that Ca ranged from 0 to $108 \mathrm{mg} / \mathrm{l}$ with a mean value of $12.26 \mathrm{mg} / \mathrm{l}$. Based on the NSDWQ [125] reference guidelines, $0.2 \mathrm{mg} / \mathrm{l}$ was suggested as the maximum permissible $\mathrm{Mg}$ concentration in drinking water. The relatively high $\mathrm{Ca}$ and $\mathrm{Mg}$ recorded in these basins have resulted in the hard water as $56.63 \%$ of groundwater in these basins is either moderately hard, hard, or very hard. Numerous epidemiologic researches carried out during recent years have established an inverse relationship between water hardness and death from cardiovascular disease. Many recommendations leave been offered concerning, the causal agent for the association between death from cardiovascular disease and water hardness. Two standards have been debated: a toxic effect brought by the contamination of lead or cadmium or a shielding effect from Ca or Mg's water content. What is vital is to limit the concentrations of these elements in drinking water. Figure $15 \mathrm{c}$ presents a synthesis of $\mathrm{Mn}$ from groundwater across the coastal basins of southwestern Nigeria. Manganese ranged from $<0.001$ to $108 \mathrm{mg} / \mathrm{l}$ with a mean concentration of $10.05 \mathrm{mg} / \mathrm{l}$. The SON has recommended $0.2 \mathrm{mg} / \mathrm{l} \mathrm{Mn}$ as the maximum permissible limit in drinking water due to the neurological disorder associated with water ingestions having a high Mn level [125]. Manganese has recently come under inspection in drinking water due to its possible toxicity and its impairment to water distribution networks. Manganese is rarely found alone in groundwater. It is often found in iron-bearing waters but is rarer than iron. Chemically it can be measured as a close relative of iron since it occurs in much the same iron forms. When manganese is available in groundwater, it is as annoying as iron, perhaps even more. At low concentrations, it produces incredibly objectionable stains on everything with which it comes in contact. Evaluation of $\mathrm{K}$ from 207 sites (Figure 15d), in the coastal basin of southwestern Nigeria, showed that $\mathrm{K}$ ranged from $<0.001$ to $341.7 \mathrm{mg} / \mathrm{l}$ with a mean value of 24.77 $\mathrm{mg} / \mathrm{l}$. Potassium is an essential electrolyte, which is a mineral required by the body to function correctly. Potassium is especially vital for nerves and muscles, including the heart. While $\mathrm{K}$ is central to human health, too much ingestion of $\mathrm{K}$ can be just as harmful as, or worse than, not getting enough. Usually, kidneys keep a healthy balance of $\mathrm{K}$ by flushing excess potassium out of the body. However, for many reasons, the level of potassium in the blood can be too high. This is called Hyperkalemia, or high potassium. The NSDWQ [125], issued no guidelines on $\mathrm{K}$ levels in drinking water. Figure $15 \mathrm{e}$ presents a synthesis of $\mathrm{Na}$ from groundwater across the coastal basins of southwestern Nigeria. Sodium concentration from 152 sites showed that $\mathrm{Na}$ ranged from $<90.001$ to $483.42 \mathrm{mg} / \mathrm{l}$ with a mean value of $38.02 \mathrm{mg} / \mathrm{l}$. There is an increasing call to use $\mathrm{K}$ in combination with $\mathrm{Na}$ to treat and soften drinking water. However, this would cause the level of $\mathrm{K}$ in drinking water to increase. The WHO found that the level of $\mathrm{K}$ found in drinking water would present no health concerns for healthy adults; though, for specific populations with comprised renal functions, such as infants or individuals suffering from specific diseases, there is the likelihood of adverse health effects. Sodium is not measured to be toxic. The human body requires $\mathrm{Na}$ to maintain blood pressure, control fluid levels, and normal nerve and muscle function. However, there are no health-based criteria for $\mathrm{Na}$ in drinking water.
Only a small amount of the Na we ingest practically comes from water. As a substitute, the standard for $\mathrm{Na}$ is based on taste. The mean $\mathrm{Na}$ concentration in these basins is below [125] recommended value (200 $\mathrm{mg} / \mathrm{l})$.

Quality assessment of groundwater in the vicinity of dumpsites in Ifo and Lagos, Southwestern Nigeria by Majolagbe, Kasali [126], showed that $\mathrm{Cd}$ concentration was below the detection limit at Ifo, whereas, mean Cd concentration was 0.005 in Lagos. In the same vein, groundwater quality assessment in a typical rural settlement (Igbora, Oyo state,) in southwest Nigeria by Adekunle, Adetunji [127], showed $\mathrm{Cd}$ concentration varies with distance from dumpsites. The Mean $\mathrm{Cd}$ concentration was $0.78 \mathrm{mg} / \mathrm{l}$ at 50 meters, $0.30 \mathrm{mg} / \mathrm{l}$ at 100 meters, $0.32 \mathrm{mg} / \mathrm{l}$ at 150 meters, and $0.30 \mathrm{mg} / \mathrm{l}$ at 200 meters away from during the dry season. Cadmium concentration was $0.34 \mathrm{mg} / \mathrm{l}$ at 50 meters, $0.32 \mathrm{mg} / \mathrm{l}$ at 100 meters, $0.30 \mathrm{mg} / \mathrm{l}$ at $150 \mathrm{mg} / \mathrm{l}$ and $0.24 \mathrm{mg} / \mathrm{l}$ at 200 meters away from dumpsite during wet season. Ayolabi, Folorunso [110]'s assessment of the municipal dumpsite system in Lagos indicated that $\mathrm{Cd}$ ranged from $<0.001$ to $0.025 \mathrm{mg} / \mathrm{l}$. There are many studies on $\mathrm{Cd}$ in these basins, but the underline reasons for higher $\mathrm{Cd}$ in groundwater need to be understood. Many studies have been carried out to decode relationships between geological environment, potable/drinking water, and diseases as they were considered to have caused suffering due to diseases among people. Chronic anaemia can be caused by protracted exposure to drink water polluted with $\mathrm{Cd}$. The Cd's accumulation is established in the kidney under such conditions, resulting in cancer and cardiovascular diseases. The NSDWQ [125] has limit Cd concentration in drinking water to be $0.003 \mathrm{mg} / \mathrm{l}$. Cadmium is restrained in drinking water because of its toxic effects on the kidney. Assessment of groundwater fluoride and dental fluorosis in Southwestern Nigeria by Gbadebo [128], revealed that groundwater samples from Abeokuta Metropolis (i.e., basement complex terrain) had F concentrations in the range of 0.65 to $1.20 \mathrm{mg} / \mathrm{l}$. These values were lower than the F contents in the groundwater samples from Ewekoro peri-urban and Lagos metropolis where the values ranged between 1.10 to 1.45 and 0.15 and $2.20 \mathrm{mg} / \mathrm{l}$, respectively. The $\mathrm{F}$ concentrations in nearly all locations were generally above the WHO recommended $0.6 \mathrm{mg} / \mathrm{l}$. The study also revealed that the $\mathrm{F}$ distribution of groundwater samples from the different geological terrain was more dependent on $\mathrm{pH}$ and TDS than on temperature. The result of the analyzed social-demographic characteristics of the residents indicated that the adults (between the age of 20 and $>40$ years) showed dental decay than the adolescent ( $<20$ years). This indicates an incidence of dental fluorosis by the high fluoride content in the populace's drinking water. Conversely, evaluation of groundwater contamination in Ibadan, South-West Nigeria by Egbinola and Amanambu [129], revealed that $\mathrm{F}$ concentration is above the recommended limits in $13 \%$ and $100 \%$ the dry and wet season samples. The occurrence of $\mathrm{F}$ in groundwater has become one of the most significant toxicological environmental hazards worldwide. Fluoride in groundwater is due to the weathering and leaching of fluoride-bearing minerals from rocks and sediments. When consumed in small quantities $(<0.5 \mathrm{mg} / \mathrm{l}), \mathrm{F}$ is advantageous in promoting dental health by reducing dental caries, but higher concentrations $(>1.5 \mathrm{mg} / \mathrm{l})$ may cause fluorosis [130]. It is projected that about 200 million people, from among 25 nations 
the world over, may suffer from fluorosis and the causes have been attributed to fluoride pollution in groundwater including Nigeria. High $\mathrm{F}$ concentration in groundwater is expected from sodium bicarbonate-type water, which is calcium deficient. The alkalinity of water also mobilises fluoride from fluorite (CaF2) [131-133]. Exposure to $\mathrm{F}$ in humans is related to:

\section{i. Fluoride concentration in drinking water}

ii. Duration of consumption; and

iii. The climate of the area. In hotter climates where water consumption is more significant, exposure doses of fluoride (F) need to be modified based on mean F intake.

Many cost-effective and straightforward measures for water defluoridation methods are already known. Nonetheless, the benefits of such methods have not reached the affected rural population due to limitations. Consequently, there is a need to develop workable plans to provide fluoride-safe drinking water to rural communities [130]. There are few studies reporting lead in groundwater from coastal basins of southwestern Nigeria. An assessment of drinking water quality using the Water Quality Index in Ado-Ekiti and environs, by Olowe, Oluyege [134], showed that $\mathrm{Pb}$ ranged from $<0.001-7.0 \mathrm{mg} / \mathrm{l}$ with a mean value of $1.94 \mathrm{mg} / \mathrm{l}$. The quality assessment of groundwater in the vicinity of dumpsites in Ifo and Lagos, Southwestern Nigeria by Majolagbe, Kasali [126], showed that $\mathrm{Pb}$ concentrations at Ifo were below the detection limit. The $\mathrm{Pb}$ level at Lagos was $0.003 \mathrm{mg} / \mathrm{l}$, and this value is below NSDWQ [125], reference guidelines. The primary reason for restraining $\mathrm{Pb}$ in groundwater is that $\mathrm{Pb}$ is associated with cancer, interfering with Vitamin D metabolism, affects mental development in infants, and is toxic to central and peripheral nervous systems.

Studies on Mercury are few in coastal basins of southwestern Nigeria. The geostatistical exploration of the dataset assessing the heavy metal contamination in Ewekoro limestone, Southwestern Nigeria by Oyeyemi, Aizebeokhai [135], showed that $\mathrm{Hg}$ ranged from 0.002 to $0.38 \mathrm{mg} / \mathrm{kg}$ with an average value of $0.12 \mathrm{mg} / \mathrm{kg}$. The absence of $\mathrm{Hg}$ reporting groundwater in these basins at the time of this study revealed a possible research gap in groundwater quality in southwestern Nigeria's coastal basins. Mercury is a scarce element in the Earth's crust, having an average crustal abundance by mass of only 0.08 parts per million (ppm). Typical Hg sources comprise volcanoes, geologic deposits of $\mathrm{Hg}$, volatilization from the ocean, and some geothermal springs. Nearly half of all $\mathrm{Hg}$ released to the environment is natural in origin. About 5,000 tons of $\mathrm{Hg}$ is released to the environment per year due to anthropogenic activities worldwide. The NSDWQ [125] has recommended $0.001 \mathrm{mg} / \mathrm{l}$ of $\mathrm{Hg}$ as the maximum permissible limit for $\mathrm{Hg}$ in drinking water due to its health effects on the kidney and central nervous system [125].

Figure $15 \mathrm{f}$ presents a synthesis of $\mathrm{Ni}$ from groundwater in coastal basins of southwestern Nigeria. Ni ranged from $<0.001$ to $9.2 \mathrm{mg} / \mathrm{l}$ with a mean concentration value of $1.84 \mathrm{mg} / \mathrm{l}$. The NSDWQ [125], set $0.02 \mathrm{mg} / \mathrm{l}$ as the maximum permissible limit of $\mathrm{Ni}$ in drinking water, because of possible carcinogenicity. The risk of developing cancer from the ingestion of $\mathrm{Ni}$ contaminated water is high in western Nigeria since the average $\mathrm{Ni}(1.84 \mathrm{mg} / \mathrm{l})$ is very much higher than the NSDWQ [125] reference guidelines. Nickel absorptions in groundwater hang on the soil use, $\mathrm{pH}$, and depth of sampling. The mean concentration in groundwater in the coastal basins of western Nigeria is $1.84 \mathrm{mg} / \mathrm{l}$. This value is very much high. Acid rain raises the mobility of $\mathrm{Ni}$ in the soil and thus might increase Ni concentrations in groundwater. In groundwater with a $\mathrm{pH}$ below 6.2 , Ni concentrations up to $0.098 \mathrm{mg} / \mathrm{l}$ have been measured. The acidic composition of groundwater sources (35.24\%) perhaps is responsible for high Ni levels in the basins. Table 4 shows silica concentrations in groundwater from Abeokuta. Silica varied markedly between the studied locations. The range was higher at Ikereku 12.5-16.4 mg/l [136]. Silica in groundwater has become an exciting element to hydrogeologists as an index to aquifers' general lithology. Groundwater travelling slowly in the subsurface will approach chemical equilibrium with minerals present in the aquifers. Under average temperature and pressure, mean silica concentrations in groundwater vary from low values of about $7 \mathrm{mg} / \mathrm{l}$ in carbonate aquifers to about $85 \mathrm{mg} / \mathrm{l}$ in aquifers containing unaltered rhyolitic ash. Groundwater from unweathered or slightly weathered basaltic aquifers generally ranges from 25 to $75 \mathrm{mg} / \mathrm{l}$ and has a mean silica value of $\sim 45 \mathrm{mg} / \mathrm{l}$.

Hypothetically, if the water were in chemical equilibrium and if the thermodynamic properties and amounts of all minerals present were known, then the exact silica concentrations of water in the subsurface might be predicted. However, many reactions involving silicate minerals are sluggish, and equilibrium cannot be assumed, mostly in highly permeable basaltic aquifers. Moreover, the types and distribution of minerals may be quite varied and hard to determine in most aquifers. Notwithstanding these complicating factors, field data indicate that silica values for any given aquifer lithology are moderately uniform.

There are many studies on copper in coastal basins of southwestern Nigeria (Figure $15 \mathrm{~g}$ ). The concentrations of $\mathrm{Cu}$ ranged from 0.01 to $19.6 \mathrm{mg} / \mathrm{l}$ with a mean value of $2.86 \mathrm{mg} / \mathrm{l}$. Dissolved $\mathrm{Cu}$ in groundwater can occasionally impart a light blue or blue-green colour and an unfriendly metallic, acrimonious taste to drinking water. Metallic $\mathrm{Cu}$ is soft, yielding, and an excellent thermal and electrical conductor. Groundwater analysis revealed high electrical conductivity, it may indicate high $\mathrm{Cu}$ concentrations, mainly if other ions, including $\mathrm{Fe}, \mathrm{Zn}$, Mn showed a lower concentration. Copper concentration is limited in drinking water since excessive ingestion $(>1.0 \mathrm{mg} / \mathrm{l})$, is associated with the gastrointestinal disorder [125]. Figure $15 \mathrm{~h}$ presents a synthesis of Fe concentrations in groundwater from coastal basins of southwestern Nigeria. The Fe's concentration was highly variable and ranged from 0 to $2.95 \mathrm{mg} / \mathrm{l}$ with a mean value of $0.31 \mathrm{mg} / \mathrm{l}$. Fe in groundwater is a direct result of its natural availability in underground rock formations and precipitation water that infiltrates through these formations as the recharge water moves through the rocks some of the iron dissolves and accumulates in aquifers which serve as a source for groundwater. Since the earth's underground rock formations contain about $5 \%$ iron, it is common to find iron in many geographical areas worldwide. Iron is naturally found in three significant forms and is rarely found in concentrations greater than $10 \mathrm{mg} / \mathrm{l}$ [137]. The degree to which Fe and Mn dissolve in groundwater hinge on the amount of oxygen in the 
Table 4: Silica concentrations in groundwater from Abeokuta.

\begin{tabular}{|c|c|c|c|c|c|c|c|}
\hline S/No & Location & No. of Sample & $\mathrm{SiO}_{2}(\mathrm{mg} / \mathrm{l})$ & S/No. Cont. & Location Cont. & No. of Sample Cont. & $\mathrm{SiO}^{2}$ (mg/l) Cont. \\
\hline $\mathrm{L} 1$ & Itoko & 3 & $7.5-8.5$ & $\mathrm{~L} 25$ & Saje & 6 & $6.9-8.2$ \\
\hline L2 & Erube & 3 & $6.2-8.0$ & L26 & Aregba & 5 & $7.5-9.0$ \\
\hline L3 & Olumo & 2 & $18.5-19.3$ & L27 & Ikija & 4 & $1.3-1.5$ \\
\hline L4 & Ijaye & 2 & $8.7-10.5$ & $\mathrm{~L} 28$ & Ikereku & 2 & $2.4-2.6$ \\
\hline L5 & Ago-Ika & 2 & $4.6-5.4$ & L29 & Efon & 3 & $2.5-3.0$ \\
\hline L6 & Adatan & 2 & $1.8-2.3$ & L30 & Bode Olude & 5 & $6.0-6.4$ \\
\hline L7 & Ake & 2 & $2.0-4.3$ & L31 & Housing Estate & 5 & $6.5-6.8$ \\
\hline L8 & Ijemo & 2 & $2.7-4.0$ & L32 & Iberekodo & 2 & $2.4-2.6$ \\
\hline L9 & Idomapa & 2 & $3.6-6.3$ & L33 & Lafiaji & 2 & $7.9-8.2$ \\
\hline L10 & Ikija & 2 & $4.0-6.0$ & L34 & Ita Elega & 7 & $3.9-4.5$ \\
\hline L11 & Kemta & 2 & $4.0-4.9$ & L35 & Mokola & 3 & $2.0-2.5$ \\
\hline L12 & Itesi & 2 & $2.3-2.6$ & L36 & Adigbe & 2 & $1.0-1.7$ \\
\hline L13 & Okejigbo & 2 & $1.9-2.3$ & L37 & Amolaso & 2 & $3.3-3.9$ \\
\hline L14 & Oke Lantoro & 2 & $0.5-1.8$ & L38 & Ibara HE & 5 & $3.8-4.7$ \\
\hline L15 & Ilugun & 2 & $3.1-3.9$ & L39 & Ijeja & 5 & $1.2-2.6$ \\
\hline L16 & Itoku & 2 & $1.4-1.6$ & L40 & Isabo & 4 & $2.1-2.5$ \\
\hline L17 & Iporo Ake & 2 & $2.4-2.6$ & L41 & Ita-Eko/Ita Iyalode & 3 & $0.5-4.6$ \\
\hline L18 & Ijeun & 2 & $8.5-9.0$ & $\mathrm{~L} 42$ & Kuto & 5 & $2.0-3.6$ \\
\hline L19 & Sapon & 2 & $3.1-4.7$ & $\mathrm{~L} 43$ & NEPA/NUD & 7 & $1.2-1.6$ \\
\hline L20 & Lantoro & 2 & $3.5-4.0$ & L44 & Oke-Sokori & 3 & $1.2-1.7$ \\
\hline L21 & Olorunsogo & 2 & $3.2-3.5$ & L45 & Oke-Ilewo & 2 & $1.3-4.7$ \\
\hline L22 & Ikereku & 2 & $12.5-16.4$ & L46 & Onikolobo & 2 & $1.4-2.6$ \\
\hline L23 & Ago Oko & 2 & $5.5-6.5$ & $\mathrm{~L} 47$ & Quarry Rd & 2 & $1.2-2.5$ \\
\hline L24 & Asero & 6 & $9.0-13.6$ & & & & \\
\hline
\end{tabular}

After Offodile [32].

water and, to a lesser extent, upon its degree of acidity, i.e., its $\mathrm{pH}$. For instance, iron can occur in two forms: as $\mathrm{Fe}(++)$ and as $\mathrm{Fe}(+++)$. When the DO level is greater than 1-2 mg/l, iron occurs as Fe3+, while at lower $\mathrm{DO}$ levels, the iron occurs as $\mathrm{Fe}(++)$. Even though $\mathrm{Fe}(++)$ is very soluble, $\mathrm{Fe}(+++)$ will not dissolve substantially. Therefore, if the groundwater is oxygen-deprived, iron (and $\mathrm{Mn}$ ) will dissolve more readily, especially if the water's $\mathrm{pH}$ is on the acidic side. The DO content is decreased with an increased aquifer depth, mainly if the aquifer contains organic matter $(\mathrm{OM})$. The $\mathrm{OM}$ decomposition depletes the oxygen in the water, and the iron dissolves as $\mathrm{Fe}(++)[138,139]$. Under these circumstances, the dissolved iron often goes with dissolved manganese or hydrogen sulfide (rotten egg smell). When this water is pumped to the surface, the dissolved iron reacts with the oxygen in the atmosphere, changes to $\mathrm{Fe}(+++)$ (i.e., is oxidized), and forms rust-coloured iron minerals. Dissolved manganese may form blackish particulates in the water and cause similar coloured stains on fixtures. The mean Fe concentration is with the [125] reference guidelines, even though high Fe ingestion in drinking water is not associated with any health hazard. Figure 15i presents a synthesis of $\mathrm{Zn}$ concentration in groundwater from the coastal basins of southwestern Nigeria. The concentration of $\mathrm{Zn}$ ranged from 0 to $45.9 \mathrm{mg} / \mathrm{l}$ with a mean value of $3.65 \mathrm{mg} / \mathrm{l}$. The Nigerian standard has set $3.0 \mathrm{mg} / \mathrm{l}$ as a maximum permissible limit of $\mathrm{Zn}$ in drinking water. Mean $\mathrm{Zn}(3.65 \mathrm{mg} / \mathrm{l})$ is above the SON limits. Zinc is an indispensable nutrient needed for good health. Too little $\mathrm{Zn}$ in the diet is associated with adverse health effects such as loss of appetite, decreased sense of taste and smell, lowered ability to fight off infections, slow growth, slow wound healing, and skin sores. Eating or drinking too much $\mathrm{Zn}$ in a short period can lead to adverse health effects, such as stomach cramps, nausea, and vomiting. Eating large amounts of $\mathrm{Zn}$ for more extended periods may cause anaemia, nervous system disorders, damage to the pancreas, and lowered required cholesterol levels. There is no evidence that zinc causes cancer in humans.

\section{Anion Chemistry}

Evaluation of $\mathrm{HCO} 3$ concentrations from 119 locations in coastal basins of southwestern Nigeria revealed that $\mathrm{HCO} 3$ ranged from 3.6 to $456.28 \mathrm{mg} / \mathrm{l}$ with a mean value of $116.98 \mathrm{mg} / \mathrm{l}$ (Figure 16a). There are no reference guidelines set up by NSDWQ [125]. Studies on $\mathrm{CO} 3$ were not accessed at the time of this study. The two ions are essential to water quality parameters because when $\mathrm{CO} 3$ and $\mathrm{HC} 03$ are joint with $\mathrm{Ca}$ and $\mathrm{Mg}$, they form carbonate hardness. However, if soil concentrates on drying solution, it advances as $\mathrm{CaCO} 3$ or $\mathrm{MgCO}$ 3. $\mathrm{Ca}$ and $\mathrm{Mg}$ decrease $\mathrm{Na}$ concentration levels and the SAR index rise, initiating an alkalizing effect and elevated $\mathrm{pH}$ levels. When groundwater analysis shows elevated $\mathrm{pH}$ levels, it may indicate the high content of carbonate and bicarbonate ions. Figure $16 \mathrm{~b}$ presents a synthesis of $\mathrm{Cl}$ concentrations in the coastal basin of southwestern Nigeria. Evaluation of $\mathrm{Zn}$ in groundwater from 203 sites across the basin revealed that it ranged from 0.12 to $387 \mathrm{mg} / \mathrm{l}$ with a mean concentration value of $47.15 \mathrm{mg} / \mathrm{l}$. The NSDWQ [125], has set 250 $\mathrm{mg} / \mathrm{l}$ as the maximum permissible allowable drinking water limit. Chloride is one of the most common anions found in tap water. Chloride generally combines with $\mathrm{Ca}, \mathrm{Mg}$ or $\mathrm{Na}$ to form various salts: for example, sodium chloride $(\mathrm{NaCl})$ is formed when $\mathrm{Cl}$ and $\mathrm{Na}$ combine. Chloride occurs naturally in groundwater but is found in 

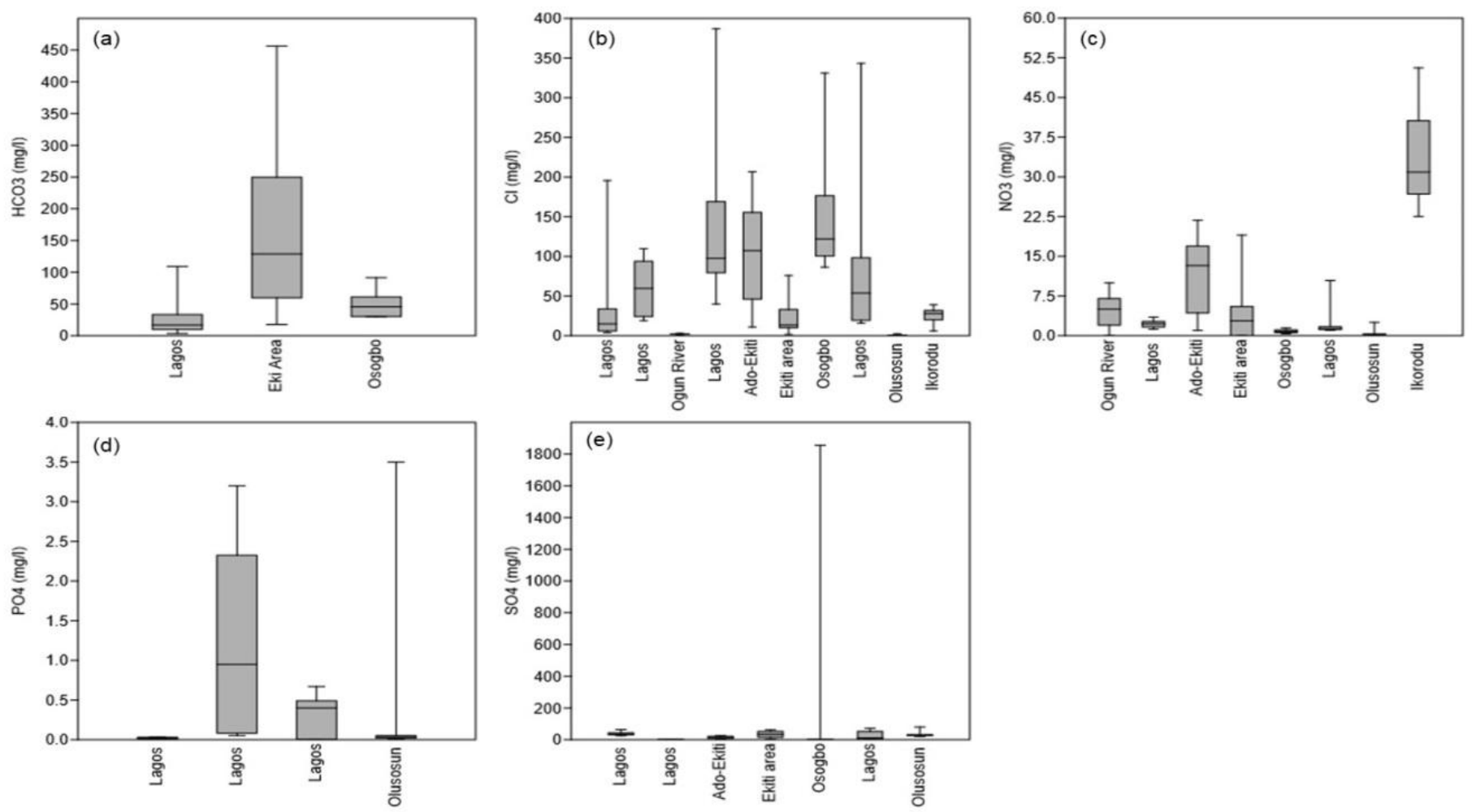

Figure 16: The anion chemistry (a) $\mathrm{HCO}_{3}$, (b) $\mathrm{Cl}$, (c) $\mathrm{NO}_{3}$, (d) $\mathrm{PO}_{4}$, and (e) $\mathrm{SO}_{4}$

high concentrations where seawater and run-off from road salts can make their way into groundwater aquifers. Although $\mathrm{Cl}$ is harmless at low levels, groundwater sources having high in $\mathrm{NaCl}$ can harm plants if used for gardening or irrigation and give drinking water an unpleasant taste. Over time, $\mathrm{NaCl}$ 's high corrosivity will also damage the water system, appliances, and water heaters, causing toxic metals. Nitrate ranged from $<0.001$ to $50.6 \mathrm{mg} / \mathrm{l}$ with a mean value of $8.81 \mathrm{mg} / \mathrm{l}$. There are very few studies on $\mathrm{NO} 2$ in coastal basins of southwestern Nigeria (Figure 16c). Akinbile and Yusoff [140]'s environmental impact of leachate pollution on groundwater supplies in Akure, Nigeria, showed that $\mathrm{NO} 2$ ranged from 0.7 to $0.9 \mathrm{mg} / \mathrm{l}$ with an average value of 0.8 $\mathrm{mg} / \mathrm{l}$. The impact of pit latrines on groundwater quality of Fokoslum, Ibadan, Southwestern Nigeria [141], showed that NO2 concentrations vary with pits' distance. The mean $\mathrm{NO} 2$ concentration was $0.12 \mathrm{mg} / \mathrm{l}$ at 10.9 meters, $0.05 \mathrm{mg} / \mathrm{l}$ at 11.8 meters, $0.12 \mathrm{mg} / \mathrm{l}$ at 13.1 meters, 0.21 $\mathrm{mg} / \mathrm{l}$ at 16.3 meters, $0.22 \mathrm{mg} / \mathrm{l}$ at 13.3 meters, $0.19 \mathrm{mg} / \mathrm{l}$ at 17.9 meters, $0.23 \mathrm{mg} / \mathrm{l}$ at 9.4 meters and $6.1 \mathrm{mg} / \mathrm{l}$ at 6.1 meters, respectively. The NO2 from these sites was below the NSDWQ [125] reference limits.

Figure 16d presents a synthesis of $\mathrm{PO} 4$ in groundwater from coastal basins of western Nigeria. The PO4 ranged from 0 to 3.5 $\mathrm{mg} / \mathrm{l}$ with a mean value of $0.65 \mathrm{mg} / \mathrm{l}$. High PO4 in drinking water is not associated with any severe health risks. The presence of PO4 in groundwater is an indicator of anthropogenic pollution since PO4 is mainly derived from organic wastes. The significance of PO4 is mostly linked to eutrophication of surface water bodies. High PO4 and NO3 in water, help plant and algal growths, leading to a variation of diurnal dissolved oxygen, blooms, and littoral slimes [142]. Figure 16e presents a synthesis of $\mathrm{SO} 4$ concentrations in groundwater from coastal basins of southwestern Nigeria. The Concentration of $\mathrm{SO} 4$ ranged from $<0.001$ to $1855 \mathrm{mg} / \mathrm{l}$ with a mean value of $52.01 \mathrm{mg} / \mathrm{l}$. The NSDWQ [125], has set $100 \mathrm{mg} / \mathrm{l}$ as the maximum allowable limit of SO4 in drinking water, even though there is no health risk associated with high ingestion of SO4 drinking water. However, high concentrations of $\mathrm{SO} 4$ in drinking water can cause diarrhoea in humans, especially infants. However, adults usually become adapted to high SO4 concentrations after a few days [143].

\section{Conclusion}

The literature is unanimous about the importance of understanding the hydrogeology and hydrochemistry of groundwater in coastal basins of southwestern Nigeria. Based on the reviewed works, the following remarks can be made:

i. In southwestern Nigeria's coastal basins, the Abeokuta group is the oldest formation in the area. This group comprised of the Ise, Afowo, and Araromi Formations. Other formations in the basin include the Akinbo and Ilaro formations. Despite the marked spatial variability of these formations, their lithology remains relatively the same.

ii. Also found in this area is the deltaic formation, which contains alluvial deposits. The Ogun Basin is the central coastal basin in western Nigeria, followed by the Osse-Owena Basin. The later has not been fully explored hydrogeologically. The Osun Basin, drained by the Osun River, covers most Osun and Ekiti States parts. This basin is not associated with good groundwater storage, since basement complex rocks underlie it. 
iii. These coastal basins were further grouped into the upper surficial aquifer system; and the intermediate aquifer system. Also found in this area is the crystalline Basement Terrain. From the hydrogeologic point of view, unweathered basement rock contains negligible groundwater; though, a significant aquiferous unit can develop within the weathered overburden and fractured bedrock. The general groundwater condition in the area showed that groundwater is very localized.

iv. Groundwater classification based on physical parameters showed mixed results, though groundwater sources are most suitable for drinking.

These basins' hydrochemistry showed groundwater is relatively good in terms of its suitability for drinking, industrial and agricultural uses. Owing to the increasing urbanization in the area, reasonable measures are required to protect groundwater from overexploitation and pollution.

\section{Acknowledgement}

Federal University Birnin kebbi supported this review. Thanks to all anonymous contributors.

\section{References}

1. Olofinlade WS, Daramola S, Olabode OF (2018) Hydrochemical and statistical modeling of groundwater quality in two contrasting geological terrains of southwestern Nigeria. Modeling Earth Systems and Environment 4: 1405-1421.

2. Arfanuzzaman M, Atiq Rahman A (2017) Sustainable water demand management in the face of rapid urbanization and groundwater depletion for social-ecological resilience building. Global Ecology and Conservation 10: 9-22.

3. Pahl-Wostl C (2019) The role of governance modes and meta-governance in the transformation towards sustainable water governance. Environmental Science \& Policy 91: 6-16

4. Rao ND, Min J (2018) Decent Living Standards: Material Prerequisites for Human Wellbeing. Soc Indic Res 138: 225-244. [crossref]

5. Ficke AD, Myrick CA, Hansen LJ (2007) Potential impacts of global climate change on freshwater fisheries. Reviews in Fish Biology and Fisheries 17: 581-613.

6. Heathwaite AL (2010) Multiple stressors on water availability at global to catchment scales: understanding human impact on nutrient cycles to protect water quality and water availability in the long term. Freshwater Biology 55: 241-257.

7. Peters NE, Meybeck (2000) Water Quality Degradation Effects on Freshwater Availability: Impacts of Human Activities. Water International 25: 185-193.

8. Jamiu AA, Robert M. Kalin, Philippe Sentenac, Ibrahim Hassan, et al. (2020) Assessing the Impact of Climate Change on Groundwater Quality of the Shallow Coastal Aquifer of Eastern Dahomey Basin, Southwestern Nigeria. Water 12.

9. Md Enamul Huq, Shah Fahad, Zhenfeng Shao, Most Sinthia Sarven, Imtiaz Ali Khan, et al. (2020) Arsenic in a groundwater environment in Bangladesh: Occurrence and mobilization. J Environ Manage 262. [crossref]

10. Zacchaeus OO (2020) Effects of industrialization on groundwater quality in Shagamu and Ota industrial areas of Ogun State, Nigeria. Heliyon 6.

11. Asiwaju-Bello YA, Olabode, Ogunsuyi MT (2020) Pollution potential and causative hydrogeochemical processes in unconfined aquifer systems in a typical urban setting: emphasis on recharge and discharge areas. Applied Water Science 10: 1-23.

12. Fan Feng, Yongfeng Jia,, Yu Yang, Huan Huan, Xinying Lian, et al. (2020) Hydrogeochemical and statistical analysis of high fluoride groundwater in northern China. Environ Sci Pollut Res Int 27: 34840-34861.

13. Jebreen $\mathrm{H}$ (2018) Recharge, geochemical processes and water quality in karst aquifers: Central West Bank, Palestine. Environmental Earth Sciences 77: 1-16.

14. Muhammad Afnan Talib, Zhonghua Tang, Asfandyar Shahab, Jamil Siddique,
Muhammad Faheem, et al. (2019) Hydrogeochemical Characterization and Suitability Assessment of Groundwater: A Case Study in Central Sindh, Pakistan. International Journal of Environmental Research and Public Health 16: 1-21. [crossref]

15. Osin OA, Yu, S Lin (2017) Oil refinery wastewater treatment in the Niger Delta, Nigeria: current practices, challenges, and recommendations. Environ Sci Pollut Res Int 24: 22730-22740. [crossref]

16. Ibe KM, PU Agbamu (1999) Impacts of human activities on groundwater quality of an alluvial aquifer: A case study of the Warri River, Delta State, SW, Nigeria. International Journal of Environmental Health Research 9: 329-334.

17. Emenike PC, CC Nnaji, IT Tenebe (2018) Assessment of geospatial and hydrochemical interactions of groundwater quality, southwestern Nigeria. Environmental Monitoring Assessment 190: 1-17.

18. Güler C (2012) Assessment of the impact of anthropogenic activities on the groundwater hydrology and chemistry in Tarsus coastal plain (Mersin, SE Turkey) using fuzzy clustering, multivariate statistics and GIS techniques. Journal of Hydrology 414-415: 435-451.

19. Huang G (2013) Impact of anthropogenic and natural processes on the evolution of groundwater chemistry in a rapidly urbanized coastal area, South China. Sci Total Environ 463-464: 209-21. [crossref]

20. Ma F (2014) Hydrochemical characteristics and the suitability of groundwater in the coastal region of Tangshan, China. Journal of Earth Science 25: 1067-1075.

21. Masoud AA (2014) Groundwater quality assessment of the shallow aquifers west of the Nile Delta (Egypt) using multivariate statistical and geostatistical techniques. Journal of African Earth Sciences 95: 123-137.

22. Badmus GO (2020) Hydrochemical analysis of groundwater quality along the coastal aquifers in part of Ogun Waterside, Ogun State, southwestern Nigeria. Heliyon 6.

23. Oyeyemi KD, AP Aizebeokhai, MA Oladunjoye (2015) Integrated Geophysical and Geochemical Investigations of Saline Water Intrusion in a Coastal Alluvial Terrain, Southwestern Nigeria. International Journal of Applied Environmental Sciences 10: 1275-1288.

24. Adelana SMA (2005) The impact of anthropogenic activities over groundwater quality of a coastal aquifer in Southwestern Nigeria. Aquifer Vulnerability and Risk, 2nd 4th International Workshop Congress on the Protection and Management of Groundwater Reggia di Colorno - Parma, 21-22-23 Settembre: p. 1-10.

25. Awomeso JA, SM Ahmad, AM Taiwo (2020) Multivariate assessment of groundwater quality in the basement rocks of Osun State, Southwest, Nigeria. Environmental Earth Sciences 79: 1-9.

26. A AJ, TA O (2013) Assessment of Groundwater Quality in Abeokuta Southwestern, Nigeria. Research Inventory: International Journal of Engineering and Science 2: 21-31.

27. Yusuf MA, TA Abiye (2019) Risks of groundwater pollution in the coastal areas of Lagos, southwestern Nigeria. Groundwater for Sustainable Development 9.

28. Aizebeokhai AP, KD Oyeyemi, ES Joel (2016) Groundwater potential assessment in a sedimentary terrain, southwestern Nigeria. Arabian Journal of Geosciences 9.

29. Akaegbobi IM, GO Ogungbesan (2016) Geochemistry of the Paleocene limestones of Ewekoro Formation, Eastern Dahomey Basin, Southwestern Nigeria: Implication on Provenance and Depositional Conditions. Ife Journal of Science 18: 669-684.

30. Ola-Buraimo AO (2014) Biostratigraphy of the Campano-Maastrichtian Uzeeba Shale deposit, Dahomey Basin Southwestern Nigeria. Elixir Geoscience 69: 2281222818 .

31. Ola-Buraimo OA (2012) Palynological Investigation of a Type Section of Early Maastrichtian Arimogija - Okeluse Shale Sequence, Dahomey (Benin) Embayment, Southwestern Nigeria. International Journal of Science \& Emerging Technologies 3: 37-45.

32. Offodile ME (2002) Groundwater Study and Development in Nigeria, second edition, Mecon Geology and Eng. Services Ltd. Pg: 1- 453.

33. Oli IC (2019) A Review of the Geology and Mineral Resources of Dahomey Basin, Southwestern Nigeria. International Journal of Environmental Sciences \& Natural Resources 21: 1-5

34. Obomighie PO, JO Gwegwe, AG Oluwadebi (2016) Petrographic Studies and Paleoenvironmental Reconstruction of Some Outcropping Sediments in Parts of Eastern Dahomey Basin, South-Western, Nigeria. IOSR Journal of Applied Geology and Geophysics 4: 9-15. 
35. Nton NE, PR Ikhane, MN Tijani (2009) Aspect of rock-eval studies of the Maastrichtian-Eocene sediments from subsurface, in the eastern Dahomey basin southwestern Nigeria. European Journal of Scientific Research 25: 417-427.

36. Olabode, S.O. and M.Z. (2016) Mohammed, Depositional Facies and Sequence Stratigraphic Study in Parts of Benin (Dahomey) Basin SW Nigeria: Implications on the Re-Interpretation of Tertiary Sedimentary Successions. International Journal of Geosciences 7: 210-228.

37. Olabode SO, JA Adekoya (2008) Seismic stratigraphy and development of Avon canyon in Benin (Dahomey) basin, southwestern Nigeria. Journal of African Earth Sciences 50: 286-304.

38. Olatinsu O (2017) Lithotype characterizations by Nuclear Magnetic Resonance (NMR): A case study on limestone and associated rocks from the eastern Dahomey Basin, Nigeria. Journal of African Earth Sciences 129: 701-712.

39. Okosun EA (1990) A review of the Cretaceous stratigraphy of the Dahomey Embayment, West Africa. Cretaceous Research 11: 17-27.

40. Adeoti L, OM Alile, O Uchegbulam (2010) Geophysical investigation of saline water intrusion into freshwater aquifers: A case study of Oniru, Lagos State. Scientific Research and Essays 5: 248-259.

41. Mohammed S, M Opuwari, S Titinchi (2020) Source rock evaluation of Afowo clay type from the Eastern Dahomey Basin, Nigeria: insights from different measurements. Sci Rep 10.

42. Adeoye JA (2020) Geochemistry and paleoecology of shales from the CenomanianTuronian Afowo formation Dahomey Basin, Nigeria: Implication for provenance and paleoenvironments. Journal of African Earth Sciences 169.

43. Nton ME, PR Ikhane, MN Tijani (2009) Aspect of Rock-Eval Studies of the Maastrichtian-Eocene Sediments from Subsurface, in the Eastern Dahomey Basin Southwestern Nigeria. European Journal of Scientific Research 25: 417-427.

44. Akaegbobi IM, GO Ogungbesan, JE Ogala (2011) Carbonate Microfacies and Major Element Content of The Paleocene - Eocene Sections Exposed at the Sagamu Quarry, Eastern Dahomey Basin, Nigeria. Global Journal of Geological Sciences 9: 241-251.

45. PR I (2012) Petrography and Geochemical Appraisal of Afowo Sandstone Facies, Dahomey Basin, Southwestern Nigeria. Chemistry and Materials Research 2: 50-59.

46. Adelana, SMA (2008) An overview of the geology and hydrogeology of Nigeria. Chapter 11. 15(11): pg: 171-198.

47. Adekeye OA (2019) Biostratigraphic Analysis of the Cretaceous Abeokuta Group in the Eastern Dahomey Basin, Southwestern Nigeria. Journal of African Earth Sciences 152: 171-183.

48. Joel ES (2019) Integration of aeromagnetic and electrical resistivity imaging for groundwater potential assessments of coastal plain sands area of Ado-Odo/Ota in southwest Nigeria. Groundwater for Sustainable Development 9.

49. Osinowo OO, AO Akanji, AI Olayinka (2014) Application of high-resolution aeromagnetic data for basement topography mapping of Siluko and environs, southwestern Nigeria. Journal of African Earth Sciences 99: 637-651.

50. Aladejana JA, AO Talabi (2013) Assessment of Groundwater Quality in Abeokuta Southwestern, Nigeria. Research Inventy: International Journal of Engineering And Science 2: 21-31.

51. Oyedele KF, EI Momoh (2009) Evaluation of Seawater Intrusion in Freshwater Aquifers in a Lagoon Coast: A Case Study of the University of Lagos Lagoon, Akoka, Nigeria. Report and Opinion 1: 1-12.

52. Adeyemi GO (2013) Geophysical and Sedimentological Characterization of a Tar Sand Rich Area in South-western Nigeria. Journal of Environment and Earth Science 2: 71-83.

53. Akinmosin A, AO Shoyemi (2010) Technical Feasibility of Direct Application of the Nigerian Tar Sand Deposits as Road Asphalt. The Pacific Journal of Science and Technology 11: 526-536.

54. Adepelumi A, B Ako, T Ajayi (2001) Groundwater contamination in the basementcomplex area of Ile-Ife, southwestern Nigeria: A case study using the electricalresistivity geophysical method. Hydrogeology Journal 9: 611-622.

55. Oyedele KF, S Oladele, C Okoh (2012) Geo-Assessment of subsurface conditions in Magodo Brook Estate, Lagos, Nigeria. International Journal of Advanced Scientific and Technical Research 2: 731-741.
56. Oteri, UO, RA Ayeni (2016) The Lagos Mega City: Water Megacities and Global Change. Available at: http://eaumega.org/wp-content/uploads/2016/05/EN-LagosMonograph.pdf,: pg: 1-36.

57. Amajor LC (1991) Aquifers in the Benin Formation (Miocene Recent), Eastern Niger Delta, Nigeria: Lithostratigraphy, Hydraulics, and Water Quality. Environmental Geology and Water Science 17: 85-101.

58. Oomkens E (1974) Lithofacies relations in the Late Quaternary Niger Delta complex. Sedimentology 21: 195-222.

59. Reijers TJA, SW Petters, CS Nwajide (1997) The Niger Delta Basin. African Basins. Sedimentary Basins of the World, 3 edited by R.C. Selley (Series Editor: K.J. Hsti) p. 151-172.

60. Adeyemi O, F Olutoyin, O Olumide (2020) Downstream hydraulic geometry across headwater channels in Upper Ogun River Basin, Southwestern Nigeria. African Geographical Review 39: 345-360.

61. Eludoyin AO, AO Adewole (2019) A remote sensing-based evaluation of an ungauged drainage basin in Southwestern Nigeria. International Journal of River Basin Management 18: 307-319.

62. Olusola A (2020) Morphologic and hydraulic variability of small bedrock and alluvial channels in relation to lithological controls, Upper Ogun River Basin, Southwestern Nigeria. Physical Geography 41: 537-557.

63. Oke MO (2015) Comparative analysis of groundwater recharge estimation value obtained using empirical methods in Ogun and Oshun river basins. Ife Journal of Science 17: 53-63.

64. Ikhile CI (2012) The Impacts of Climate Change on the Discharge of OsseOssiomo River Basin, South Western Nigeria under Different Climatic Scenarios. An International Journal of Science and Technology Bahir Dar, Ethiopia 1: 1-13.

65. Catherine II, O Lekan (2007) Application of GIS in land-use studies in the OsseOssiomo River basin, Nigeria. Remote Sensing for Environmental Monitoring and Change Detection (Proceedings of Symposium HS3007 at IUGG2007, Perugia, July 2007). IAHS Publ. 316: 245-251.

66. Solomon O, O Prince (2013) Flood Frequency Analysis of Osse River Using Gumbel's Distribution. Civil and Environmental Research 3: 55-59.

67. Oke MO (2013) Comparative Analysis of Empirical Formulae Used in Groundwater Recharge in Ogun - Oshun River Basins. Journal of Scientific Research \& Reports 2: 692-710.

68. Adepelumi AA (2009) Delineation of saltwater intrusion into the freshwater aquifer of Lekki Peninsula, Lagos, Nigeria. Environmental Geology 56: 927-933.

69. Bayewu OO (2017) Geophysical evaluation of groundwater potential in part of southwestern Basement Complex terrain of Nigeria. Applied Water Science 7: 46154632 .

70. Lateef TA (2012) Geophysical Investigation For Groundwater Using Electrica Resistivity Method - A Case Study Of Annunciation Grammar School, Ikere Lga, Ekiti State, South-Western Nigeria. IOSR Journal of Applied Physics 2: 1-6.

71. Fashae OA (2014) Delineation of groundwater potential zones in the crystalline basement terrain of SW-Nigeria: an integrated GIS and remote sensing approach. Applied Water Science 4:19-38.

72. Egbinola CN (2014) Amanambu, Christiana Ndidi Egbinola* and Amobichukwu Chukwudi Amanambu. SpringerPlus 3: 1-6.

73. Akinyemi FO (2013) An assessment of land-use change in the Cocoa Belt of southwest Nigeria. International Journal of Remote Sensing 34: 2858-2875.

74. DeSimone LA, JP Pope KM (2020) Ransom, Machine-learning models to map pH and redox conditions in groundwater in a layered aquifer system, Northern Atlantic Coastal Plain, eastern USA. Journal of Hydrology: Regional Studies 30.

75. Laluraj CM, G Gopinath (2006) Assessment on seasonal variation of groundwater quality of phreatic aquifers - a river basin system. Environ Monit Assess 117: 45-57.

76. Takem GE (2015) Acidification of shallow groundwater in the unconfined sandy aquifer of the city of Douala, Cameroon, Western Africa: implications for groundwater quality and use. Environmental Earth Sciences 74: 6831-6846.

77. Douglas TM, LS Robert (2015) Corrosion Control by Deposition of $\mathrm{CaCO}_{3}$ Films: Part 1, A Practical Approach for Plant Operators. American Water Works Association 69: 592-599. 
78. Marc, E., R.S. Michael, and E.M. Travis (1996) Alkalinity, pH, and copper corrosion by-product release. American Water Works Association.

79. Gouda VK (1970) Corrosion and Corrosion Inhibition of Reinforcing Steel: I. Immersed in Alkaline Solutions. British Corrosion Journal 5:198-203.

80. Melidis P (2007) Corrosion control by using indirect methods. Desalination 213: 152-158.

81. Asare-Donkor NK, DD Wemegah, AA Adimado (2013) Chemical Analysis of Freshwater Bodies in the Kumasi Metropolis and Its Environs, Ghana. Journal of Environment and Earth Science 3: 37-45.

82. Bacha AA, MI Durrani, PI Paracha (2010) Physical and Bacteriological Characteristics of Drinking Water of Peshawar. Pakistan Journal of Nutrition 9: 1028-1033.

83. Haziq MA, NA Qani (2017) Physiochemical Assessment of Drinking Water Quality in Kandahar City, Afghanistan. International Journal of Innovative Science and Research Technology 2: 7-24.

84. Timothy AO, KH M (1978) The effect of $\mathrm{pH}$ and hardness metal ions on the competitive interaction between trace metal ions and inorganic and organic complexing agents found in natural waters. Water Research 12: 703-711.

85. Karthikeyan S, PLR Palaniappan, S Sabhanayakam (2007) Influence of pH and water hardness upon nickel accumulation in edible fish Cirrhinus mrigala. Journal of Environmental Biology 28: 489-492.

86. Ruiz-Ramirez J (2005) Relationship between water content, $\mathrm{NaCl}$ content, $\mathrm{pH}$ and texture parameters in dry-cured muscles. Meat Sci 70: 579-587.

87. Florides G, S Kalogirou (2007) Ground heat exchangers-A review of systems, models and applications. Renewable Energy 32: 2461-2478.

88. Green TR (2011) Beneath the surface of global change: Impacts of climate change on groundwater. Journal of Hydrology 405: 532-560.

89. Keery J (2007) Temporal and spatial variability of groundwater-surface water fluxes: Development and application of an analytical method using temperature time series. Journal of Hydrology 336: 1-16.

90. Alva G, Y Lin, G Fang (2018) An overview of thermal energy storage systems. Energy 144: $341-378$.

91. Zhu S (2020) Using seasonal temperature difference in underground surrounding rocks to cooling ventilation airflow: A conceptual model and simulation study. Energy Science \& Engineering 8: 3457-3475.

92. Boulton AJ, PJ Hancock (2006) Rivers as groundwater-dependent ecosystems: a review of degrees of dependency, riverine processes and management implications. Australian Journal of Botany 54: 133-144.

93. Humphreys WF (2008) Hydrogeology and groundwater ecology: Does each inform the other?. Hydrogeology Journal 17: 5-21.

94. Strona G (2019) AQUA LIFE Software: A New Tool for a Standardized Ecological Assessment of Groundwater Dependent Ecosystems. Water 11: 1-17.

95. Hayashi M (2004) Temperature-electrical conductivity relation of water for environmental monitoring and geophysical data inversion. Environmental Monitoring and Assessment 96: 119-128.

96. Beddows PA (2007) Decoupled fresh-saline groundwater circulation of a coastal carbonate aquifer: Spatial patterns of temperature and specific electrical conductivity. Journal of Hydrology 346: 18-32.

97. Sargaonkar A, V Deshpande (2003) Development of an overall index of pollution for surface water based on a general classification scheme in Indian context. Environmental Monitoring and Assessment 89: 43-67.

98. Zakir HM (2017) Quality and Metallic Pollution Level in Surface Waters of an Urban Industrialized City: A Case Study of Chittagong City, Bangladesh. Journal of Industrial Safety Engineering 4: 9-18.

99. Güler C, M Alpaslan (2009) Mineral content of 70 bottled water brands sold on the Turkish market: Assessment of their compliance with current regulations. Journal of Food Composition and Analysis 22: 728-737.

100. Karavoltsos S (2008) Evaluation of the quality of drinking water in regions of Greece. Desalination 224: 317-329.

101. Naveen BP (2017) Physico-chemical and biological characterization of urban municipal landfill leachate. Environmental Pollution 220: 1-12.
102. Rubenowitz-LundinKevin, E. and K.M. Hiscock, Water Hardness and Health Effects. In: Essentials of Medical Geology. Revised Edition. Eds: O. Selinus. Springer Dordrecht Heidelberg New York London, 2013: pg: 1-808.

103. Ghernaout (2018) Combining lime softening with alum coagulation for hard Ghrib dam water conventional treatment. International Journal of Advanced and Applied Sciences 5: 61-70.

104. Richards CS (2018) A 21st-Century Perspective on Calcium Carbonate Formation in Potable Water Systems. Environmental Engineering Science 35: 143-158.

105. Farrell C (2018) Turbidity composition and the relationship with microbial attachment and UV inactivation efficacy. Sci Total Environ 624: 638-647.

106. Edwards AC, PJA (2008) Withers, Transport and delivery of suspended solids, nitrogen and phosphorus from various sources to freshwaters in the UK. Journal of Hydrology 350: 144-153.

107. Appleyard, S, T Cook (2008) Reassessing the management of groundwater use from sandy aquifers: acidification and base cation depletion exacerbated by drought and groundwater withdrawal on the Gnangara Mound, Western Australia. Hydrogeology Journal 17: 579-588.

108. Mushtaq N (2018) Hydrogeochemical and isotopic evaluation of groundwater with elevated arsenic in alkaline aquifers in Eastern Punjab, Pakistan. Chemosphere 200: 576-586.

109. Sabarathinam C, H Bhandary, A Al-Khalid (2020) Tracing the evolution of acidic hypersaline coastal groundwater in Kuwait. Arabian Journal of Geosciences 13: 1-19.

110. Ayolabi EA, AF Folorunso, OT Kayode (2013) Integrated Geophysical and Geochemical Methods for Environmental Assessment of Municipal Dumpsite System. International Journal of Geosciences 4: 850-862.

111. Awomeso JA (2010) Studies on the pollution of waterbody by textile effluents in.Lagos, Nigeria. Journal of Applied Sciences in Environmental Sanitation 5: 353-359.

112. Omale DO, EO Longe (2008) An assessment of the impact of abattoir effluents on River Illo, Ota, Nigeria. Journal of Environmental Science and Technology 2: 56-64.

113. Siljic Tomic A (2018) A linear and non-linear polynomial neural network modelling of dissolved oxygen content in surface water: Inter- and extrapolation performance with inputs' significance analysis. Sci Total Environ 610-611: 1038-1046.

114. Voisin J (2018) Aquifer recharge with stormwater runoff in urban areas: Influence of vadose zone thickness on nutrient and bacterial transfers from the surface of infiltration basins to groundwater. Sci Total Environ 637-638: 1496-1507.

115. Ward, C.P. and R.M. Cory (2020) Assessing the prevalence, products, and pathways of dissolved organic matter partial photo-oxidation in Arctic surface waters. Environ Sci Process Impacts 22: 1214-1223.

116. Baldock JA, JO Skjemstad (2000) Role of the soil matrix and minerals in protecting natural organic materials against biological attack. Organic Geochemistry 31: 697-710.

117. Chu L (2009) Progress and perspectives of sludge ozonation as a powerful pretreatment method for minimization of excess sludge production. Water Res 43: 1811-22.

118. Wali SU, N Alias, SB Harun (2020) Quality reassessment using water quality indices and hydrochemistry of groundwater from the Basement Complex section of Kaduna Basin, NW Nigeria. SN Applied Sciences 2.

119. Wali, SU, N Alias, BH Sobri (2020) Hydrogeochemical evaluation and mechanisms controlling groundwater in different geologic environments, Western Sokoto Basin, Northwestern Nigeria. SN Applied Sciences 2.

120. Longe, EO, LO Enekwechi (2007) Investigation on potential groundwater impacts and influence of local hydrogeology on natural attenuation of leachate at a municipal landfill. International Journal of Environmental Science and Technology 4: 133-140.

121. Izah, SC, AL Srivastav (2015) Level of arsenic in potable water sources in Nigeria and their potential health impacts: A review. Journal of Environmental Treatment Techniques 3:15-24.

122. WHO, Guidelines for drinking-water quality: Fourth edition incorporating the first addendum. WHO Library Cataloguing-in-Publication Data. World Health Organization Geneva 2018: 631 .

123. Odukoya AM, AF Abimbola (2010) Contamination assessment of surface and groundwater within and around two dumpsites. International Journal of Environmental Science and Technology 7: 367-376. 
124. WHO, Guidelines for drinking-water quality: First Addendum to Third Edition Recommendations. World Health Organization Geneva, 2006 1: 595.

125. NSDWQ, Nigerian Standard for Drinking Water Quality: Nigerian Industrial Standard NIS 554. Standards Organisation of Nigeria, 2007: 30 .

126. Majolagbe AO, AA Kasali, LO Ghaniyu (2011) Quality assessment of groundwater in the vicinity of dumpsites in Ifo and Lagos, Southwestern Nigeria. Advances in Applied Science Research 2: 289-298.

127. Adekunle IM (2007) Assessment of Groundwater Quality in a Typical Rural Settlement in Southwest Nigeria. International Journal of Environmental Research and Public Health 4: 307-318.

128. Gbadebo AM (2012) Groundwater fluoride and dental fluorosis in southwestern Nigeria. Environ Geochem Health 34: 597-604.

129. Egbinola CN, AC Amanambu (2014) Groundwater contamination in Ibadan, SouthWest Nigeria. SpringerPlus 3: 1-6.

130. Jha SK (2013) Fluoride in groundwater: toxicological exposure and remedies. Journal of Toxicology and Environmental Health, Part B 16: 52-66.

131. Adimalla N, S Venkatayogi (2016) Mechanism of fluoride enrichment in groundwater of hard rock aquifers in Medak, Telangana State, South India. Environmental Earth Sciences 76:1-10.

132. Jha SK (2013) Fluoride in groundwater: toxicological exposure and remedies. Toxicol Environ Health B Crit Rev 16: 52-66.

133. Singh CK (2011) Application of GWQI to Assess Effect of Land Use Change on Groundwater Quality in Lower Shiwaliks of Punjab: Remote Sensing and GIS-Based Approach. Water Resources Management 25: 1881-1898.

134. Olowe B, J Oluyege, O Famurewa (2016) An Assessment of Drinking Water Quality Using Water Quality Index in Ado-Ekiti and Environs, Nigeria. American Chemical Science Journal 12:1-7.
135. Oyeyemi KD, AP Aizebeokhai, HI Okagbue (2017) Geostatistical exploration of dataset assessing the heavy metal contamination in Ewekoro limestone, Southwestern Nigeria. Data Brief 14: 110-117.

136. Gbadebo AM, AM Taiwo, AJ Adeola (2013) Assessment of Dissolved Silica Content of Groundwater from Southwestern Nigeria. Journal of Human Ecology 43: 273-279.

137. Ityel D, Groundwater: Dealing with iron contamination. Available at https://www. sciencedirect.com/science/article/abs/pii/S001518821170043X. Retrieved on 09/09/2020, 2011: 1-3.

138. Noffke A (2012) Benthic iron and phosphorus fluxes across the Peruvian oxygen minimum zone. Limnology and Oceanography 57: 851-867.

139. Spuhler D, J Andrés Rengifo-Herrera, C Pulgarin (2010) The effect of Fe2+, Fe3+ $\mathrm{H} 2 \mathrm{O} 2$ and the photo-Fenton reagent at near-neutral $\mathrm{pH}$ on the solar disinfection (SODIS) at low temperatures of water containing Escherichia coli K12. Applied Catalysis B: Environmental 96: 126-141.

140. Akinbile CO, MS Yusoff (2011) Environmental Impact of Leachate Pollution on Groundwater Supplies in Akure, Nigeria. International Journal of Environmental Science and Development 2: 81-86.

141. Ahaneku IE, PA Adeoye (2014) Impact of Pit Latrines on Groundwater Quality of Fokoslum, Ibadan, Southwestern Nigeria. British Journal of Applied Science \& Technology 4: 440-449.

142. EPA, Parameters of water quality: Interpretation and Standards. An Ghniomhaireacht um Chaomhnu Comhshaoil. Ireland. 2001 1-132.

143. Miao Z (2012) Sulfate reduction in groundwater: characterization and applications for remediation. Environ Geochem Health 34: 539-50.

\section{Citation:}

Wali SU, Dankani IM, Abubakar SD, Gada MA, Uma KJ (2021) Detailed Hydrogeological and Hydrochemical Reassessment of Coastal Basins of Southwestern Nigeria. Geol Earth Mar Sci Volume 3(1): 1-25. 